\title{
Ulus, Uluslaşma ve Devlet: Bir Modern Kavram Olarak Ulus Devlet
}

\author{
Nation, Nationality and State: Nation State as a Modern Concept
}

Rifat AYDIN*

\section{Öz}

Son üç yüz yıldır ulus devletler uluslararası sistemin kurucu unsuru ve oyuncusu konumundadır. İmparatorluklar çağının sona ermesi ile beraber art arda gelen devrimler (Fransız Devrimi ve Sanayi Devrimi) beraberinde yeni bir devlet örgütlenmesini getirmiştir. Böylece toplumsal ve siyasal hayatın oluşumu ve gelişimi ulus devletler üzerinden şekillenmiş ve bu oluşma durumunun felsefi arka planını milliyetçi ideoloji doldurmuştur. Milliyetçi söylem ile şekillenen bu yeni devlet biçimi beraberinde bir ulus olma durumunu ve bu ulusa uygun insanın inşasını da getirmiştir. Bu çerçevede çalışma ulus devlet yapısını Avrupa'da (ve daha sonra tüm Dünya’da) ortaya çıkaran süreçleri farklı düşünürlerin tezlerini karşılaştırarak açıklamayı amaçlamaktadır. Bu kapsamda çalışmada, milliyetçilik - ulus devlet ilişkisi tarihsel bir perspektifle ele alınılacak ve ulus devletin oluşumunda rol alan farklı içsel ve dışsal faktörler irdelenecektir. Bu çerçeve ulus devletin ortaya çıkışını açıklayan teoriler dört başlıkta sınıflandırılarak (ekonomik, inşacl, sosyo-kültürel ve askeri temelli) karşılaștırmalı bir şekilde incelenecek. İlk olarak Immanuel Wallerstein ve Etienne Balibar'ın başını çektiği ekonomik temelli milliyetçilik teorisi ele alınacak olup milliyetçiliğin, sosyalist ideolojilerin "ezilenlerin temsilcisi” rolünü özellikle Üçüncü Dünyảda nasıl devraldığını ve bu ülkelerin ulus devlet kurma süreçlerindeki rolüne değinilecektir. Daha sonra modernleşmenin bağımlı değişkeni olarak "inşacı" yaklaşımın milliyetçilik - ulus devlet ilişkisi perspektifi, Ernest Gellner ve Benedict Anderson başta olmak üzere icat edilen milletler ve/veya hayal edilen cemiyetler olarak ulus devletlerin nasıl kurgulandığına ilişkin tezler incelenecektir. Üçüncü bir yaklaşım olarak ise Stein Rokkan’nn temsil ettiği sosyo-kültürel etmenlerin ulus devletin oluşumundaki etkisi araştırılacaktır. Bu araştırmada state formation süreci Rokkanıın kavramlaştırması üzerinden sunulacaktır. Yine Antony Giddens ve Hagen Schulze’nin yaklaşımları da bu başlık altında açıklanacaktır. Modern devletin oluşum sürecinin en önemli unsurlarından birini askeri (ordu) ve bu bağlamdaki savaş pratikleri oluşturmaktadır. Savaşlar ve güvenlik politikaları, modern ulus devletin kurulmasında, iktidarın merkezileștirilmesinde ve kurumsallaşmasında belirleyici bir role sahip olmuştur. Bu çerçevede özellikle Charles Tilly’nin savaş ile ulus devlet arasında kurduğu ilişkide kullandığg "zor", "sermaye" ve "zorlaştırılmış sermaye" kavramları incelenerek Avrupa milletlerinin ulus devletler halini alması sürecinde askeri süreçlerin etkisi incelenecektir. Çalışma; ulus devlet - milliyetçilik ilişkisinde bu dört farklı yaklaşımın tezlerini karşılaştırarak bu yaklaşımların üstünlük ve zayıflıklarını sunacak; Diğer taraftan ulus devleti ortaya çıkaran süreçlerin etki boyutunu da ele alacak; Son aşamada ise askeri temelli yaklaşımın diğer yaklaşımlara göre ulus devletin oluşumunu açıklamada sunduğu avantajlara yer verecektir.

Anahtar Kelimeler: Ulus, Ulus Devlet, Milliyetçilik, Modernleşme ve Savaş

Başbakanlık Uzmanı, Gazi Üniversitesi Sosyoloji Bölümü Doktora Öğrencisi, rifataydin7@hotmail.com. 


\begin{abstract}
For the last three hundred years nation-states have been the founding element and player of the international system. The revolutions (French Revolution and Industrial Revolution), along with the end of the empire era, brought together a new state organization. Thus, the formation and development of social and political life is shaped through nation states, and the philosophical background of this state of formation is filled with nationalist ideology. This new form of state, shaped by nationalist discourse, has brought about the formation of a nation as well as the construction of a man suitable for this nation. This framework aims to explain the process of bringing nation-state structure to Europe (and then the whole world) by comparing the theses of different thinkers. In this context, the relationship between nationalism and nation-state will be analyzed from a historical perspective and different internal and external factors taking part in the formation of the nation state will be examined. Theories explaining the emergence of this framework nation state will be examined in a comparative way, classified in four categories (economic, constructivist, socio-cultural and military based). First, the theory of economic-based nationalism, led by Immanuel Wallerstein and Etienne Balibar, will be addressed and will refer to the role of nationalism, the "representative of the oppressed" of socialist ideology, especially in the Third World, and its role in the nation-state building process. Then the theses of the "constructivist" approach to modernization as a dependent variable will be examined as to how nation states are constructed as invented nations and / or imagined societies, particularly nationalism-nation state-related perspectives, Ernest Gellner and Benedict Anderson. As a third approach, the influence of the socio-cultural factors represented by Stein Rokkan in the formation of the nation state will be investigated. In this research the state formation process will be presented through Rokkan's conceptualization. The approaches of Antony Giddens and Hagen Schulze will also be explained under this heading. One of the most important elements of the formation process of the modern state is the military (army) and the war practices in this context. Wars and security policies have played a decisive role in the establishment of the modern nation-state, the centralization and institutionalization of power. In this context, the effects of military processes will be examined in the process of the European nations becoming nation states by examining the concepts of "difficult", "capital" and "hardened capital" that Charles Tilly uses in connection with the nation state of war. Work; will present the advantages and weaknesses of these approaches by comparing the theses of these four different approaches in relation to nation state - nationalism; On the other side, it will also address the extent of the effects of processes that bring about the nation state; At the last stage, the military-based approach will have advantages in explaining the formation of the nation-state according to other approaches.
\end{abstract}

Keywords: Nation, National State, Nationalism, Modernization and War

\title{
Giriş
}

Son üç yüz yıl boyunca siyasi tarihin yönü imparatorluk çağından merkezi devletlere doğru evrilmiştir. Yeni devlet örgütlenmesi egemenliğini hanedana veya Kiliseye değil halka dayandıran ulus devlet yapılanması şeklinde ortaya çıkmıştır. Batı Avrupa'da doğan ulus devletler günümüze gelindiğinde tüm dünyada hâkim devlet yapılanması biçimini aldığından, ulus devlet ve onunla yakın ilişkili milliyetçilik kavramları güncelliğini korumaktadır. Bu çalışma bu bağlamda ulus devleti ortaya çıkaran siyasal, kültürel ve ekonomik dinamikleri açılayacaktır. Ayrıca ulus devlet aşamasına tarihsel olarak hangi süreçlerle ve devrimlerle ulaşıldığı milliyetçilik bağlamında ele 
değerlendirilecektir. Bu kapsamda dört temel yaklaşım etrafında ulus devletin ortaya çıkışı ve bu süreçte milliyetçiliğin oynadığı işlevsel rol üzerinde durulacaktır.

Ulus devleti ortaya çıkaran birçok farklı dinamik vardır. Bu kapsamda bu farklı dinamiklerin nasılı ile bu dinamikleri besleyen süreçler dört farklı yaklaşım altında incelenecektir. Bu yaklaşımlar sırasıyla ekonomik temelli, inşacı, sosyo-kültürel ve askeri temelli olmak üzere ayrıştırılacak ve bu başlıklar etrafında milliyetçilik ile ulus devlet ilişkisi ele alınacaktır. Özellikle milliyetçiliğin Avrupadaki serüveni bağlamında ortaya çıkan farklılaşmaların tarihsel - sosyolojik temellerini açıklamaya çalışacak olan bu çalışma, son tahlilde ulus devletin oluşumunu indirgemecilikten kaçınarak çoklu dışsal ve içsel faktörler bağlamında farklı düşünürlerin tezlerini karşılaştırmalı bir yaklaşımla sunacaktır.

Bu kavramlaştırma yapılırken iki temel sorunla karşılaşıllmıştır. Bunlardan ilki, bir yazarın ulus devlet ve milliyetçilik ilişkisi konusundaki düşüncesinin burada sunulan kategorilerin bir veya birkaçına girebilme durumudur. Bu problem, yazarın tezinin temeline yerleştirdiği argümanın bu başlıklardan hangisine daha yakın olduğuna göre değerlendirilerek çözülmeye çalışılmıştır. İkinci sorun ise burada yapılan ayrımın modernleştirici teorileri temel almasıdır. Bilindiği üzere özselci (ilkçi) yaklaşım modernleştirici teorinin aksine ulusu çok eski dönemlere dayanan ve etnisiteyi temel alan bir yaklaşımla ele almaktadır. Bu çalışma bu kapsamda özselci yaklaşımı kavramlaştırmasının dişında tutmuş, ancak modernleştirici teorilerin açımlanması açısından bu çalışma çerçevesinde kısmen vurgulanmıştır. Bu vurgu ulus devletin oluşumunda benimsenen indirgemeci yaklaşımdan hem kaçınmanın sonucu olarak hem de ulus devletin oluşumuna etki eden litaratürde tartışılan bir yaklaşımın tamamen gözden uzak tutulmamasını amaçlamaktadir.

İlk olarak ulus devleti ekonomik değişim ve gelişimin bir sonucu olarak gören yaklaşımı inceleyecek olan bu çalışma, daha sonra ulus devleti hayal edilmiş veya icat edilmiş bir olgu olarak kabul eden inşacı yaklaşımı ele alacaktır. Ulus devletin ortaya çıkışını açıklayan diğer bir çalışma ise sosyo-kültürel yaklaşımdır. Bu yaklaşım Avrupa'da meydana gelen sosyo-kültürel değişimlerin ulus devletin temelini attığını savunmaktadır. Bu çerçevede özellikle Stein Rokkan’ın dört aşamada açıkladığı ulus devletleşme süreci incelenecektir.

Modern devletin oluşum sürecinin en önemli unsurlarından birini ordu ve bu bağlamda savaş ve diğer güvenlik pratikleri oluşturmaktadır. Tarihsel olarak ele alındığında savaşların ve güvenlik politikalarının, modern ulus devletin kurulmasında, iktidarın merkezileştirilmesinde ve kurumsallaşmasında belirleyici olmuştur. Bu çerçevede özellikle Tilly’nin savaş ile ulus devlet arasında kuruduğu ilişkide kullandığı "zor”, "sermaye” ve "zorlaştırılmış sermaye” kavramları incelenerek Avrupa milletlerinin ulus devletler halini alması sürecinde ortaya çıkan farklı yollar karşılaştırılacaktır. Son tahlilde çalışma ulus devlet milliyetçilik ilişkisinde temelde modernleşme ile ulus devlet arasında ilişki kuran bu dört farklı boyutta kategorize edilen yaklaşımların üstünlük ve zayıflıklarını sunmayı ve ulus devleti ortaya çıkaran etmenlerin etki boyutunu göstermeyi amaçlamaktadır. 


\section{Kavramsal Olarak Ulus Devlet ve Milliyetçilik}

Bernard Lewis, millet sözcüğünün Aramice'den geldiğini ve "bir söz” anlamına gelen "milla" kökenine dayandığını belirtmekte ve "bir kutsal kitabı kabul eden insan topluluğu”nu ifade ettiğini söylemektedir. Etimolojisindeki dinsel anlam doğrultusunda millet sözcüğü daha çok aynı dine inanan insan topluluklarını ifade ederken, Moğolca kökenden gelen ve "nation" sözcüğü karşılığında kullanılan "ulus” sözcüğü ise daha çok, farklı bir etnik topluluğu belirtmektedir. (Karyelioğlu,2012, s.143) Roskin ise ulus kelimesinin Latince kökeninin (bugünkü anlamından farklı olarak) soy bağı anlamına geldiğini iddia etmektedir. (2014, s.1) Güncel Latince sözlükte ise "nation"; doğum, ırk, sınıf anlamlarında kullanılmaktadır. (http:// www.latin-dictionary.org/natio) Ulus kelimesi ve kavramı bütünüyle siyasi ve felsefi bireyciliği merkeze alan ve kendini sadece modern demokrasilerde bulan bir anlama haizdir. (Leca,1998, s.11) Bu manada ulus, modern döneme ait ve onunla anlam kazanan bir olgudur. Sosyolojik açıdan ulus aynı kültür ve egemenlik alanı üzerindeki kültürel, ekonomik ve siyasal sistemlerin çakışma süreçleriyle birlikte yerel kültürlerin standartlaşarak merkezi iktidar tarafından desteklenen bir üst kültür ile bağlamlanmasını ifade eder. Siyasal açıdan ise ulus hem bir bireyler topluluğu olarak oluşturulan bir grup, hem de diğer uluslara göre siyasal bir bireyi temsil etmektedir. (Leca,1998, s.13-14) Michel Foucault’a göre tarihsel süreç içerisinde artık kendini anlatan devlet değildir, başka bir şey kendisini tarihsel anlatının nesnesi olarak ön plana çıkarmaktadır. Bu şeyin adı ulustur. Milliyet, ırk, sınıf gibi kavramlar bu ulus kavramının etrafında kendisini üretecektir. (2004, s.152)

Dünya toplumlarının, ulus öncesi toplumsal oluşumlardan/yapılardan, ulus olma aşamasına varma sürecinin hem bir ürünü hem de ideolojik aracı olarak tanımlanabilecek olan "milliyetçilik" ise bir kavram olarak ilk kez 1774 yılında Johann G. Herder tarafından kullanılmıştır. (Uzun,2003, s.143144) Milliyetçilik ulusal topluluk duygusu etrafında devlet ve toplum arasında bir köprü işlevi görmüştür. Milliyetçilik bu açıdan kendi kökenini oluşturan bir süreçtir. Milliyetçi intelijansiya ${ }^{1}$ bizzat kendilerince inşa edilen şeyleri veri olarak alır. Bu verilerin başarılı bir şekilde üretimi ulus devletin inşasının ilk aşamasına denk düşmektedir. (Leca,1998, s.14) Anthony Giddens da benzer bir vurguyla milliyetçiliği, siyasal bir düzen içinde yer alan bireylerin ortak bir geçmişe ve kültüre sahip olduklarını vurgulayan simgeler ve inançlar sepetine duydukları psikolojik bir bağlılık duygusu olarak tanımlamaktadır. (2008, s.286-288) Milliyetçilik toplumun aynı siyasal otoriteye aidiyet duyarak homojenleştirilmesi ile siyasal ve ulusal sınırları birbiriyle uyumlu kılmayı hedefleyen bir güçtür. (Boztemur,2006, s.166) Yine milliyetçilik modern toplumlara has özeliklerle yakından ilişkilidir ve devlet ile toplum arasında var olduğu savunulan ayrımı kapatmayı hedefler. (Breuilly,2000, s.187-188) Slavoj Zizek ise milliyetçiliği toplumsal farklılıkları ideal bir homojenleştirilmesi ve demokrasinin öznesi olan yurttaşın üretiminin en önemli aracı olarak görür. Milliyetçilik toplumsal keyfin ete kemiğe bürünmüş halini temsil eder. Bu keyfilik “öteki” üzerinden kendini inşa eden ve tanımlayan "beni” tekleștiren bir görünüme sahiptir. (2012, s.220)

1 Batı dillerine Rusçadan geçen bu kavram bir ülkedeki aydın topluluğunu ifade etmektedir. (Bknz: Meriç, C. (2005). Mağaradakiler. 12. Baskı. İstanbul: İletişim Yayınları, 64-70.) 
Ulus ve milliyetçilik kavramlarının bu etimolojik tarihsel yolculuğu milliyetçi akımların yoğunluk kazandığ 1 19. yüzyıldan itibaren siyaset biliminin en önemli konularından olan "ulus devlet" kavramının ana omurgasını oluşturmaya başlamıştır. Günümüzde milletlerarası hukukun asıl aktörü olan ulus devlet, 1648 yılında imzalanan Westfalya Anlaşması’ndan sonraki üç yüz yıllık gelişmelerin ürünüdür. Modernleşme süreci sonunda artık devlet, hem millî birlik ve bütünlüğün tek temsilcisi, hem de sosyal sözleşmeden kaynaklanan iktidarın tek sahibidir. Modern devlet oluşturulurken millî egemenliğin sağladığı meşruluk zemininde, birey, millet ile birlikte siyasi iktidarın sahibi olan devletle özdeşleşmiştir. Hukuk ve siyaset alanında, ulus devletin normatif yapısı nesnel olarak ele alınırken, sübjektif yanı da ihmal edilmemiştir. Millî egemenliği savunan milliyetçilik; siyasi birim (devlet) ile toplumsal birimin (millet) çatışmasını engelleyen bir araç işlevi görmüştür. (Işıklar, 2008, s.800)

Ulus devlet yoğun bir şekilde milliyetçiliğe atıfta bulunan siyasi bir kurumdur. Bu kurum devlet millet birlikteliğini merkeze alan ve kendini bu beraberlik üzerinden anlamlandıran bir görünüme sahiptir. Çünkü ulus devletlerin kurulmasıyla birlikte, sosyal entegrasyon için milliyetçilik önemli bir araç olmuştur. Yani kavmiyetçilik yerini milliyetçiliğe, alt kültürler de üst kültüre bırakmıştır. Böylece standartlaşmanın bir aşaması olarak üstün diller milliyetçilik bağlamında üretilmiş ve bu diller milliyetçiliğin taşıyıcıları olmuştur. Dil üzerinden başlayan bu süreci tarih, kültür ve geleneğin dönüşümü izlemiştir. (Yıldırım, 2006, s.185) 19. yüzyılla birlikte ulus kavramı üzerinde özellikle Fransız ve Alman yazarlar arasında başlayan tartışma; milliyetçilik ulus devlet ilişkisinde tartışılan önemli bir konuya odaklanmıştır: Ulus devlet mi milliyetçiliği üretti, yoksa milliyetçilik mi modern ulus devleti ortaya çıkardı? Bu tartışmada Fransız ekolü milliyetçilik için bir ulus devletin varlığını ön şart olarak kabul ederken; Alman düşünürler milliyetçiliğin ulus devleti oluşturduğunu savunmaktaydı. Bu farklılaşma beraberinde iki yaklaşımı getirmiştir. Birinci yaklaşım ulus devletin ortak bir dile ve etnisiteye dayanması gerektiğini savunurken; diğer yaklaşım farklı bireyler topluluğunun ortak bir ulusu paylaşması olarak ulus devleti algilamaktadır. (Jaffrelot, 1998, s.54)

Ulus ve milliyetçilik arasındaki yoğun ilişki bu iki kavram arasındaki farklılıkların göz ardı edilmesine neden olmamalıdır. Bütün milliyetçilikler bir ulusa dayanmakla birlikte ulus, milliyetçiliği anlamada tek kıstas değildir. Diğer taraftan milliyetçilik çoğunlukla üst ideal hedefler etrafında kendisini oluşturan bir ideolojidir ve bir meşrulaştırma ve seferber etme aracıdır ama aynı zamanda kişisel ve kolektif inançlara dair değerleri de içinde barındırmaktadır. (Delannoi,1998, s. 32)

\section{Modern Ulus Devletin Ortaya Çıkışı}

15. yüzyıldan itibaren ortaya çıkan reform hareketleri Hristiyan dünyasında hareketlenmeye ve değişim yoluyla sosyal yapıyı dönüştürmeye zorlamıştır. Ayrıca bu dönemde ekonomide meydana gelen farklılaşma; hayat şartlarının değişmesine, soyluların tek başına güç odağı olmaktan çıkmasına neden olmuştur. (Çam, 2005, s.193-195) Örneğin feodal dönemde kendi ülkesinin 
içinde dahi güvenle gezemeyen bir tüccar artık ulus devletin arkasında bir güç olarak durması ve "yurttaş" sıfatı sayesinde ülkeler arasında gezebilmektedir. Ulus devleti ortaya çıkaran asıl dönüm noktası ise Amerikan ve Fransız devrimleri olmuştur. (Beriş, 2008, s.492-493) Fransız Devrimi öncesi meydana gelen sosyo-kültürel olaylar kurulacak yeni ulus devletin zeminini hazırlamıştır. Fransız Devrimi sonrası ise bu zeminin oluşturduğu durumun meyvelerinin toplandığ dönem olmuştur. Ulus devletin kendini tarihsel süreç içerisinde ortaya koymasını kolaylaştıran diğer önemli süreç ise moderniteye geçişi belirleyen dört devrimdir. Bu devrimler: Bilimsel, siyasal, kültürel ve endüstriyel devrimdir.

Bilimsel Devrim Newton’la başlamıştır. Evrensel yer çekimi kanunu iki dünya görüşü arasında bir kopuşa neden olmuştur. Doğrudan Tanrı tarafından yönetilen bir doğadan, kendini düzenleyen bir doğaya; tanrısal işlemleri yansıtan ve Tanrı'nın ihtişamını anlatan bir doğadan, doğanın yasalarının belirlenimciliğinden başka bir şeyi dile getirmeyen bir gök mekaniğine geçilmiştir. Orta çağ evreni, insan ve dünyanın iki yönünün-maddi ve manevi - organik bir bütün oluşturduğunu simgesel olarak ifade etme olanağı sağlıyordu. Doğanın tümü, başka bir gerçeklik düzenine bağlı bir gerçeklik olarak kavranıyor ve yaşanıyordu. İnsan bir aracıydı, çünkü görünen ve görünmeyen, madde ve ruh onda birleşmişti. Her varlığın, temelini kendisinin de ötesinde, gerçekliğin öteki katlarıyla ilişki içerisinde bulunduğu ve böylece kavradığı simgesel bir kültür vardı. İçinde insanın doğadan koptuğu ve yeniden bulmaya çalışacağı bölünmüş bir dünya, bu simgesel birliğin yerini aldı. Bundan böyle fiziksel evren, mekanik olarak düzenlenmiş, determinizme boyun eğen ve insanın yasalarını keşfetmek zorunda olduğu bir evren halini almıştır. Siyasal devrim ise modern demokrasinin devletin tek rasyonel biçimi haline gelişini ifade etmektedir. Artık modern devlet ancak demokratik olmaktadır. Bu devrimde önemli olan, iktidarın temelidir. Artık iktidarın temeli, halktan gelmektedir. İktidar ulus haline gelen bir halkın onayıyla meşruiyet kazanabilmektedir. Bununla birlikte sadece meşruiyette yeterli değildir aynı zamanda akla da uygun olmalıdır. Kültürel devrim düşüncenin laikleşmesi olarak algılanmaktadır. Düşüncenin laikleşmesi ise, her alanda tüm ölçütlerin rasyonelleşmesi anlamına gelmektedir. Toplumsal yaşamın temellerinin sadece rasyonel temeller olabileceği vurgulanmaktadır. Endüstriyel devrim ise, emeğin soyutlanmasıyla karakterize edilmektedir. $\mathrm{Bu}$, insanla doğa arasında aracı konumda bulunan teknik yapının daha bir özerklik kazanması anlamına gelmektedir. Bu devrimle, emek süreci üretici insana değil makineye bağlıdır. Soyutlama, emek sürecinin parçalarının bizzat kendilerinin mekanikleşmesiyle gerçekleşmektedir. Bütün burada aktarılan devrimler zorunlu olarak ulus devlet içinde diğer bir deyişle moderniteyle kendini gösteren yeni siyasal organizasyonun kendine özgü süreçlerinde gerçekleşmektedir. (Jeanniere, 2000, s. 95-102)

Tarihsel olarak ulus devletler dönemi feodal dönemin bitmesinin ardından baş göstermiştir. Avrupa’da meydana gelen ticari atılım ve iş bölümündeki artışın yarattığı etkiler, Avrupa'da geleneksel yapıları aşındırmıştır. 17. ve özellikle de 18. yüzyıllarda haritalar, eskinin tersine dünyayı muğlak hatlar yerine, kesin sınırlarla düzgün bir biçimde bölünmüş toprak parçaları halinde konumlandırmaya başlamıştır. Bu durum dünyanın git gide daha çok Avrupa’nın sömürgesine bölünmesiyle birlikte sınır kontrollerinin başlamasından kaynaklanmaktaydı. Bu 
dönüşümün temelinde ise, dünyanın, doğal olarak farklı ve her biri kendi siyasal birimleriyle veya devletleriyle irtibatlı uluslara bölünmüş olduğu düşüncesi yatmaktaydı. Uluslara bölünmüş olma düşüncesi öncelikle kendini askeri alanda göstermiştir. Özellikle artan savaş baskısına karşı (Napolyon Savaşları) yöneticiler, paralı asker yerine vatandaş ordularını seferber ederek, halkları, daha güçlü bir ortak kimlik etrafında toplayabilmek için başvurdukları ulus fikri etkili bir çözüm olmuştur. (Calhoun, 2012, s.19) Bir bakıma Fransız Devrimiyle ileri sürülen eşitlik, özgürlük, kardeşlik fikirleri etnik kimliği aşan bir yuttaşlık ile ortaya çıkmışken, askeri alanda fetihçi, kendi sınırlarını aşma saikiyle Fransız ulusuna evrilmiş ve en baştaki fikirler kendisini milliyetçilik ile bir arada bulmuştur. Diğer taraftan bu süreç (Napolyon savaşlarının genişlemeci ve fetih süreci) Almanya başta olmak üzere diğer Avrupa ülkelerinde milliyetçiliği uyarıcı bir işleve dönüşmüştür. (Karatani, 2017, s.373) Diğer bir ifadeyle, ulus devletin emperyalist genişlemeci etkisi başka ve yeni ulus devletlerin yaratılmasına neden olmuştur. (Arent, 2016, s.19)

Ulus devletlerin ortaya çıkışı Avrupa'da başlamıştır ve birçok sosyo - ekonomik faktör bu süreci aşama aşama hazırlamıştır. Fransız Devrimi ise ihtiyacı dolduracak unsura ad konulduğu nokta olmuştur. Ancak sanayi devrimi ile birlikte işçi sınıfının yükselişi toplumsal yapıda yeni mücadele alanları açmıştır. Aynı zamanda sanayi devrimiyle birlikte artan sömürgeleşme yarışı Almanya örneğinde olduğu gibi milliyetçiliğe farklı anlamlar ve değerler yüklemiştir. Böylece milliyetçilik tüm ulusu motive etme ve bir amaç doğrultusunda güdüleme noktasında önemli bir manivela işlevi üstlenmiştir. Ulus devletler oluşan bu yeni toplumsal yapının siyasi, iktisadi ve sosyal alanlardaki ihtiyaçlarını karşılamıştır. Ticaretin artması güvenlik ve ulaşım sektörlerine yatırımı zaruri kılmıştır. Burjuva sınıfının bir güç odağı haline gelmesi ve soylularla çatışmaya başlaması bu iki sınıf arasındaki rekabetin düzenlenmesini gerektirmiştir. Feodal yapının köylüleri artık ücret almaya başlamışlardır ve köylü taşradan (sınıfından) çıkmıştır. Bütün bu sorunlar ve süreçler ulus devletleri doğurmuştur. Oluşan bu yeni yapı toplumsal çatışmaları beraberinde getirdiyse de; milliyetçilik bu çatışmaları hafifleten bir araç olarak kullanılmıştır. Bir olgu olarak ulus devletin siyasi, toplumsal ve iktisadi açılardan bireylere benimsetilmeye çalışılması bazı ortak sembollerin kullanılmasını zorunlu kılmıştır: ortak dil, tek millet, tek devlet, tek vatan ve tek bayrak. Ortak sembollerin, en başta devlet olmak üzere siyasal ve sosyal sistemlerin ve gündelik hayatta kullanılan ortak dilin oluşturduğu kaynaklar toplumun güvenlik sorunlarını, siyasi ve sosyal sorunlarını toplumsal barış çerçevesinde istikrara sokmakla kalmamış; aynı zamanda devlet kimliği üzerinden hem diğerlerine hem de kendi içindeki zararlılara karşı ortak bir güç unsuru da oluşturmuştur.

Ulus devlet ortaya çıktığı dönem açısından incelendiğinde iki temel unsur dikkat çekmektedir. Birincisi politik sadakatin yeni iktidar biçimine evrilmesi, ikincisi ise modernleşmenin yarattığ bireyin ve bir bütün olarak toplumun siyasal nitelik kazanarak yurttaş (vatandaş) olmasıdır. Bu iki konunun sebep olduğu değişim kolay olmamıştır. Politik sadakatin yönlendirilmesinde toplum, toplumun siyasallaşmasında ise yönetici sınıf muhafazakâr bir tutum sergilemiştir. Bu muhafazakâr tutum zaman zaman kan akmasına neden olan çatışmalarla son bulmuştur. Toplumun politik sadakatinin yeni bir yönetime yönlendirilmesi oldukça sancilı olmuştur. Ancak politik sadakatin oluşturulabilmesi için modernitenin siyasal ayağını oluşturan otoritenin 
doğasını ve iktidarın kaynağını radikal bir şekilde değiştiren siyasal devrim, ulus devletin temel dayanağı olmuştur. Otoritenin halka ya da ulusa içkinliği geleneksel iktidar yapılarını değiștirerek, hak taleplerine ve bunlar için yapılan devrimlere alt yapı hazırlamıştır. (Jeanniere, 2000, s.100)

Ferdinand Tönnies’e göre modern toplumların gelişmesi ile beraber hâkim olan topluluk (Gemeinschaft) ilişkileri yerini aşamalı olarak topluma (Gesellschaft) terk edecektir. Preendüstriyel toplumsal ilişkiler ağı olan Gemeinschaft'da insanlar cemaat duygusu çerçevesinde bir arada yaşarlar. Dayanışma ruhunun ve ortak bir iradenin mevcut olduğu yapıda toplumsal ilişkiler samimidir. Yaşamın temel birimi ailedir ve köylerdeki topluluklar kendilerini geniş bir aile olarak görürler. Durağan olan bu toplum yapısında statüler doğuştan gelmektedir. Bu nedenle sınırlı bir toplumsal değişmeden söz edilebilir. Gesellschaft'ta ise bu yapıların yerini hukuk, sözleşme, rasyonellik, para ekonomisi ve kamuoyu almaktadır. Kişilerin mekânlara olan bağımlılıkları azalır; özel yaşam değerli hale gelir; kişisel çıkar temel değer haline gelir. Modernleşme süreci ilerledikçe Gemeinschaft yerini Gesellschaft’a bırakmıştır. (Bozkurt, 2009, s.159-160) Gesellschaft'in hüküm sürdüğü devlet biçimi ise ulus devlet olmuştur.

İktidarların topluma olan ihtiyaçlarındaki muazzam artış iktidarın halk ile paylaşılması yani demokrasi ile sonuçlanmıştır. (Sarıbay, 2000, s.86-87) Siyasal devrimle iktidarın demokratik bir biçim kazanmaya başlaması özellikle Fransız devriminden sonra egemenlik kavramının nasıl anlaşılması gerektiğini şekillendirmiştir: artık egemenlik “ulusal” bir içerik kazanmıştır. Başka bir ifadeyle devlet otoritesi ulusun varlığıyla özdeşleşir ve siyasal toplum doğrudan kurucu bir irade olarak ulusun rızasına bağlanır. Diğer taraftan ulusal egemenlik kuramı, tek kişiye dayalı hükümet sistemlerine karşı halkın çoğunluğundan güç alan temsilî demokrasinin kurumsallaşmasını sağlamıştır. Fransız Devrimi’nin ilk dönemi, ulusal egemenliğin gerçek anlamını bulması açısından temsilî ve doğrudan demokrasi yandaşlarının tartışmalarına sahne olmuştur. Ancak gerek Devrim'in öncüsü durumunda bulunan burjuvazinin sınıfsal çıkarları, gerekse siyasetin pratikleri, temsilî demokrasinin daha "gerçekçi”" bir model olarak belirmesine neden olmuştur. Ulus devlet modeli aracılığıyla temsilî demokrasinin kurumsallaşması sağlanmıştır. $\mathrm{Bu}$ modelde, bireyler, yurttaş sıfatıyla, halk ya da ulus kimliği içerisinde bütünleşirler ve bu bütünleşme, bireylerin tekil iradelerinin, en azından kamusal alanda, dikkate alınmamasını, tamamının iradesinin "genel irade" çatısı altında bir araya gelmesini ifade eder. (Ağaoğluları, 1991, s.22-23) Bireylerin kolektif iradesinin yansıması olarak ele alınmaya başlanan modern ulus devlet, yalnızca "ulus" haline gelen bir halkın onayını alacak yasal akılcı otoriteye dayanmaktadır.

Jürgen Habermas ulus devletleri üç aşamada açıklamıştır. İlk olarak bu devletler, birbirinden ayrı yaşayan etnik grupların barışçı yollarla tek tek devletleşmesiyle değil, komşu bölgelere, soylara, yerel kültürlere, dil ve din topluluklarına sirayet ederek ortaya çıkmıştır. Ulus devletin bu şekilde gerçekleşmesi, tarihsel bakımdan da ilktir. İkinci olarak yeni ulus devletler de genelde, asimile edilmiş, baskı altına alınmış ya da marjinalleştirilmiş topluluklar pahasına oluşmuştur. Ulus devlet, homojen bir halka dayanmak zorunda olduğu halde, bu ikinci tip ulus devlet, homojen bir topluluğa dayanmamakla beraber, homojen bir toplum oluşturmak ister. Burada 
söz konusu olan toplum, doğal olarak bir araya gelmiş homojen bir toplum değil, yapay olarak oluşturulmaya çalışılan bir toplumdur. Bu tarz ulus devletlerde devlet, demokratik olmaktan uzaklaşabilmektedir. Son olarak da etno-milliyetçi akımların ortaya çıkmasıyla gerçekleşen yeni ulus devletler ise, neredeyse her zaman kanlı saflaştırma töreleriyle gerçekleştirilmiştir ve yeni azınlıkları sürekli yeni baskıların altına almıştır. (2002, s.16-18)

Ulus devletlerin ortaya çıkmasında 15. yüzyılın sonu ile 17. yüzyılın sonu arasında yaşanan savaşların sonucunda askeri ve siyasi otoritenin merkezileşmiş olmasının, bu merkezileşmenin bir sonucu olarak daha fazla verginin devletler tarafından toplanabilmesinin, devletlerin otoritelerini kullanabilmeleri için gerekli olan bürokratik mekanizmalara sahip olmaya başlamalarının etkileri olmuştur. Bu süreçte feodal yapı çözülmüş ve toplumsal gruplar kendi aralarındaki ilişkileri değişik sözleşmelere dayandırmak durumunda kalmışlardır. Feodalitenin çözülmesi sürecinde değişik birimler arasında meydana gelen savaşlar, Avrupa'daki değişik halklar arasında farklılıkların artmasına ve aralarında nefret duygusunun yaygınlaşmasına neden olmuştur. Bu durum daha sonraki dönemlerde milletlerin ortaya çıkmasında etkili olan faktörlerden biri olmuştur. Bu çerçevede Gerd Baumann, ulus devletleri uzlaşmaz gibi görünen iki farklı felsefenin bir birleşimi olarak görmektedir; amaç ve verimliliğe başvurmayı gerektiren "akılcılık" ve eylemlerin temeli olarak duygulara başvurmayı öngören "romantizm". Ulus devlet 19. ve 20. yüzyılın meşruiyet elde etmiş devletidir. Milliyetçilik ise ulus devletin ideolojisidir. Milliyetçiliğin ortaya çıkışı ile ulus devletlerin ortaya çıkışları aynı döneme denk gelmektedir. Ulus devletler ilk olarak Avrupa'da Fransa, Almanya ve İtalya gibi devletlerde ortaya çıkmış, daha sonradan ise Doğu Avrupada ve dünya çapında görülmeye başlanmıştır. Ulus devlette meşruiyet kaynağı, din, soy veya krallık olmaktan çıkmış ve laik, demokratik yapı içerisinde kendini ifade etmeye başlamıştır. (2006, s. 25-26)

Milletleri belirli ve tarihsel olarak fazla uzak olmayan bir döneme ait gören Eric J. Hobsbawn, milletlerden ancak toprağa bağlı devletler ortaya çıktıktan sonra bahsedilebileceğini savunmaktadır. Bu yüzden de devlet ve milleti birbirinden bağımsız düşünmek imkânsızdır. $\mathrm{Bu}$ noktada Gellner’e başvuran Hobsbawn, milliyetçiliğin önceden var olan kültürleri alıp ve onları millete dönüştürdüğünü; bazen de onları icat edip veya çarpıttığını ileri sürer. (Özkırımlı, 2015, s.145) Hobsbawm, bugün millet (nation) olarak kavranan birimin belirleyici kriterlerinden birisi olarak belirli bir territoryal politik örgütlenmeyi, yani, belirli bir arazi üzerinde politik bir hükümranlık tesis edecek bir yapılanmayı öngörür.(2014,s.41-44) İdeolojinin ekonomik boyutuna ise milli ekonomi düşüncesi damgasını vurmaktadır. Bu noktada milliyetçi ideoloji de; kendi ekonomik kaynaklarına sahip olabilmenin -ki bu dikkat edilirse coğrafi bütünlüğe ve ulusal egemenliği de işaret eder - önemli bir ulus olma kriteri olduğunu vurgulamaktadır. Dolayısıyla, milliyetçilikte ulusun ekonomik gelişmesini esas alan, milli kaynaklara ve pazara yön verebilen bir devlet anlayışı da söz konusudur ki bu durumun devletin egemenliğini koruma veya arttırmayla da alakalı bir gelişme olduğu söylenebilir. (Hobsbawm, 2014, s.45) Ekonomik manada milliyetçi ideoloji, serbest ekonomiye kapıları kapatmayan ancak devlet ve ekonomiyi birbirine bağlı gören bir ideoloji görünümündedir. Buna göre; milli kaynaklara tam olarak hâkim 
olma, bunları en verimli şekilde kullanma, milli rekabet gücünü arttıracak politikaları geliştirme gibi hususlarda ulus devlet önemli işlevsel rol oynamıştır.

19. yüzyılda modern ulus devletler genel olarak, kendilerinden önceki devlet sistemlerinin aksine sınırları kesin bir toprak bütünlügüne sahiptirler. Bu topraklar askerî açıdan savunulabilecek, olabildiğince sürekli coğrafi sınırlarla çevrilidir. Devletin tek bir para birimi ve maliyesi vardır. Genellikle tek bir ulusal dil vardır ve bu dil diğer lehçelerden üstün tutulmuştur. Son olarak tek bir hukuk düzeni vardır. Bu yapının kurulmasında batılı devletler milliyetçiliği önemli bir araç olarak görmüşlerdir. Çünkü bu birleşme arzusu çoğu kez dirençle karşılaşmıştır ve bu direnci aşmada milli duygular önemli bir avantaj sağlamıştır. (Poggi, 2005,s.114)

\section{Ulus Devletin Oluşumuna İlişkin Kuramlar}

Ulus devlet birçok içsel ve dişsal faktörün etkisi altında tarihsel süreçte ortaya çıkmıştır. Bu girift ve kapsamlı olguyu anlama noktasında birçok farklı açıklama yapılmıştır. Bu açıklamalar birçok farklı unsuru bağımlı değişken olarak tezlerinin merkezine yerleştirmiştir. Bu kapsamda aşağıda dört temel yaklaşım (ekonomik, inşacı, sosyo-kültürel ve askeri temelli) boyutunda, bu teoriler açıklanacak, zayıf ve güçlü yönleri vurgulanacaktır.

\section{Ulus Devletin Oluşumunda Ekonomik Temelli Yaklaşım}

Ekonomik temelli bakış açısı çok temel olarak üretim biçimlerinin devleti ve değişimi biçimlendirdiği iddiasındadır. Ulus devletin doğası gereği ortaya çıkabilmesi için öncelikle bünyesinde var olması gereken iki öğenin ulus ve devleti bir araya getirmesi gerekmektedir. Ancak ulus devletin ortaya çlkabilmesi için önce sermaye-devletin ortaya çıkabilmesi yani sermaye ile devletin bir araya getirilmiş olması gerekmektedir. (Karatani, 2017, s.290) Bu teoriye göre devlet, kapitalist meta üretiminin bir ürünü olarak görülmektedir. (Tilly, 2001, s.32) Bu yaklaşımın önemli temsilcilerinin başında Immanuel Wallerstein ve Etienne Balibar gelmektedir. Balibar, devletin kurduğu cemaate kurgusal etniklik demekte ve hiçbir ulusun doğal olarak etnik bir temelinin olmadığını savunmaktadır. Ancak toplumsal oluşumlar ulusallaştıkça, içerdikleri, paylaştıkları veya hükmettikleri toplulukta etnikleşir ya da sanki kendiliğinden bir ilk kimliğe kavuşur. (2013, s.119) Wallerstein ise ulus devlet ve milliyetçilik kavramlarını "dünya sistemi” şeklinde adlandırdığı tarihsel kapitalist çerçeve içerisindeki hiyerarşikleşme bağlamında ele almakta, ulus, milliyetçilik, etnisite, ırk ve halk gibi kavramları tartışarak bu kavramları sistem içerisindeki iktisadi yapıyla ilişkilendirmektedir. Buna göre, ırk kavramı dünya ekonomisindeki eksenel ${ }^{2}$ iş bölümüyle, yani merkez-çevre zıtlığıyla, ulus kavramı ise bu tarihsel sistemin siyasal üstyapısıyla, yani devletlerarası sistemi biçimlendiren ve ondan türeyen egemen devletlerle, etnik grup kategorisi ise, sermaye birikiminde ücretsiz emeğin büyük payının korunmasını sağlayan hane yapılarının yaratılmasıla ilgilidir. (2013, s. 98)

2 Wallerstein dünya ekonomisini, merkez, çevre ve yarı çevre olarak temelde sömüren sömürülen dikotomosi üzerinden tanımlamakta ve Dünya üzerindeki iş bölümünün de bu ayrılmayı destekleyecek şekilde geliştiğini ifade etmektedir. 
Wallerstein, modern devletin kendine özgü bir yapısı olduğunu belirtir ve modern devletin en belirgin özelliğinin egemenlik iddiasında bulunması olduğunu savunur. Bu devletle ilgili olmaktan ziyade, devletlerarası sistemle ilgili bir durumundur ve içeriye ve dişarıya dönük olmak üzere iki yönlü bir iddiadır. İçe dönük olarak, devletin hiçbir kişi, kurum veya grubu dikkate almak zorunda olmaksızın gerekli gördüğü bütün düzenlemeleri yapabileceği ve sınırlar dahilinde yaşayan herkesin bunlara uymasının zorunlu olduğudur. Dışa dönük olarak ise, hiçbir devletin başka bir devletin içişlerine yönelik bir müdahalesinin olamayacağını kabul eder. Modern dünyada egemenlikten söz edebilmek için karşılıklı tanıma olgusunun gerçekleşmesi bir zorunluluktur. (Abdulvahap, 2012, s.71-73) Devletlerarası sistemde neden her özel egemen devletin kuruluşunu bir ulus veya halk tasavvuruna dayandırıldığı sorusunu ise Wallerstein şöyle açıklar; bu sistemde (kapitalist) devletin kaynaşma sorunu vardır, çünkü devletler bir kez egemen olduktan sonra kendilerini iç parçalanma ve dış saldırı tehdidi altında bulurlar. Tam bu noktada "ulusal duygular" geliştiği ölçüde bu tehditleri azaltır. Wallerstein sonuç olarak ırk ve milliyetçiliğin kapitalist sistemdeki işlevini; ırksal sınıflandırmanın esas olarak merkez çevre zıtlığını koruma ve ifade etmenin, buna karşı milliyetçiliğin köken olarak, hiyerarşik düzenin yavaş fakat düzenli değişimi içinde devletlerarasındaki rekabeti ifade etmenin bir tarzı olduğu şeklinde açılklar. (2013, s.101-102)

Ulus devletin ortaya çıkışı, ekonomik etkinliğin her şeyden daha çok önem kazandığı bir tarihsel döneme denk gelmektedir. Wallerstein bunu kapitalizmin eşitsiz doğasının bir sonucu olduğunu söyler. Marx’tan farklı olarak, bunun düz ve basit bir örtüşme olmadığını, tam tersine çelişkili bir durumu ortaya çıkardığını iddia etmiştir. Çünkü Wallerstein’e göre, eğer liberal ekonomistlerin söylediği gibi sermaye tamamen piyasa marifetiyle işleyen bir olgu ise kapitalizmin milliyetçiliği doğurmuş olduğu düşüncesi yanılmaya mahkûmdur. Ancak yaşananlar bunun tersine gelişmiştir, kapitalizm çağ 1 sonu gelmez bir milliyetçilik çağ 1 olmuştur. Bunun nedeni ise kapitalizmin hiç de liberallerin iddia ettiği gibi işlememesidir, Wallerstein’e göre kapitalizmin insanlığa dayattığı zorunlu proleterleşme, maliyetleri sürekli yükselten bir eğilim doğurmaktadır. Bu yüzdende, maliyetleri azaltmak için kapitalizm nüfusları çeşitli kategorilere bölmüştür ve milliyetçilik bu bölünmenin aracı olmaktadır. (Öğün, 2000, s.75)

Toplumların yerelliklerinden ve kandaşlıklarından koparak ulusal pazar çerçevesinde toplanması ile oluşmakta olan ulus devletin ortaya çıkışını Bottomore ise şöyle açıklar; "Başta Batı Avrupa ile Kuzey Amerika'da olmak üzere ulus devletlerin ortaya çıkışı iki ana koşula dayanmaktaydı; birincisi, mutlak monarkların 16. yüzyıldan 18. yüzyıla kadar gerçekleştirdikleri, modern merkezi yönetimin gelişimi, diğeri ise belli bir toprak parçasının üzerinde yaşayan, kendini farklı bir etnik ve kültürel karaktere sahip gören ve hanedan yönetiminin yerine halk egemenliğini kurmak için savaşım veren bir toplumsal küme için kendi kaderini kendisinin belirlemesi siyasal fikrini ele geçiren milliyetçiliğin doğuşuydu." (Bottomore’dan aktaran; Güldiken,2006, s.157)

Ekonomik temelli yaklaşım, milliyetçiliği sadece egemen devletlerin kendi uyrukları arasındaki dayanışmayı sağlamlaştırmaya veya onlar üzerindeki kontrolünü arttırmaya yönelik ideolojik bir yöntem olarak görür. Bu yaklaşıma göre ulus ise hiyerarşik bir dünya düzeninin ürünüdür. 
(Jaffrelot,1998, s.55-56) Bu teori özellikle sömürülen ülkelerde sosyalizmden ziyade milliyetçiliğin ön plana çıkması ile ilişkilidir ve bu sorunsalı açıklamaya yöneliktir. Yine determinist bir yorumla ekonomik değişkenin dışındaki diğer sosyo-kültürel ve tarihsel dinamikler göz ardı edilmektedir. Bu teori son dönemde Katalonya, İskoçya gibi bölgelerde artan ayrılıkçı talepleri açıklamaktan da uzaktır.

\section{Ulus Devletin Oluşumunda “inşacı” Yaklaşım}

Milliyetçiliği her şeyden önce siyasette ve iktidarla ilişkilendiren Breuilly ikinci adım olarak da milliyetçiliği modernleşme süreciyle ve onun yeni devlet biçimiyle ilişkilendirmiştir. Buna göre, modernleşme iş bölümünde temel bir değişim içerir yani geleneksel birleşik iş bölümünden işlevsel iş bölümüne geçilmiştir. Bu yüzdende artık Kilise, monarşi ve köylü komünleri toplumsal yaşamı kontrol etmede yetersizdir çünkü artık Kilise tüm işlevleri kontrol etmekten uzaktır. Ancak bu değişim ve yeni ulus devletin kurulumu çok kolay olmayacaktır. Milliyetçilik de bu noktada önem kazanmaktadır. Ulus devlet artık vatandaşına siyasi katılım aracılığıyla bir kimlik vermekte ve vatandaşlık bağı ile siyasal meşruiyeti sağlamlaştırmaktadır. (Özkırımlı,2015, s.131-132) Bu iş bölümüne atıfta bulunan Anderson, ulus olarak tanımlanan bu yapıların, basit bir şekilde dinsel cemaatlerin ve hanedanlıkların mülklerinin içinden çıkarak onların yerini aldığını düşünmenin dar görüşlülük olduğunu söylemekte ve bu sürecin, bu eski yapıların, dünyayı kavrama tarzında meydana gelen köklü bir değişimi algılayamamalarında yattığını vurgulamaktadir. (Anderson,2014, s.37)

Avrupa’da özellikle mutlak monarşi döneminde ve sonrasında ortaya çıkan devletlerin modernliği, idari kapasitelerini arttırmalarının yattığını iddia eden Calhoun eskinin dolaylı yönetim biçimlerinin yerine, toprakları ve halkları daha doğrudan bir denetime ve müdahaleye başvuran bir devlet yapılanmasına geçildiği iddia eder. Ancak bunun sağlanması için homojen ve itaatkâr bir ulus yaratma yolu tercih edilmiştir. Bunun içinde eğitim sistemini, dini sinıflamalar ve etnik damgalamalar kullanılmıştır. Calhoun devletle uluslaşma arasında bu ilişkiyi kurmakla beraber, ulusun devletin oluşumunun basit bir türevi olmadığını iddia eder. Ulusun rolü modern genel irade ve kamuoyu kavramları temelinde sınırları belli, adına halk dediğimiz ve kendi içinde bütünleşmiş bir topluluğun devamlılı̆̆ını sağlamasındadır. Başka bir deyişle halkın kum taneleri gibi her tarafa saçılmış ya da ailelere bölünmüş değil de, toplumsal olarak bütünleşmiş olması önemlidir ve bunun sağlayıcı dinamizmi kendini milliyetçilikte ve millet olma güdüsünde bulmaktadır. Calhoun'a göre, milliyetçilik, siyasi otonomi ve self-determinasyona yönelik modern iddiaların üstün nitelikli formu olmuştur. (2012, s. 97-99)

Hans Kohn milliyetçilik anlayışının, yöneten ve yönetilenlerin, sınıf ve kastların ilişkisinde esaslı bir durum değişikliği olmadan ve tabii halk egemenliği fikri oluşmadan ortaya çıkamayacağını söyler. Çünkü milliyetçilik ile tabii hukuk doktrini ve devletin egemenlik anlayışı seküler bir forma dönüşmekteydi. Bu yönüyle milliyetçiliğin yayılması, aslında halk kitlelerinin ortak bir siyasi forma bürünmesi yani ulus devletleri inşa etme sürecinin bir aracı olmadan öte bir değeri yoktur. Kohn'a göre milletlerin inşa edilmesinde en önemli dış faktör, ortak bir toprağa ya da 
daha doğrusu devlete sahip olmaktır. Milliyetleri kurmaya yönelik grupları kanalize eden itici unsur bu siyasi sınırlardır. Aynı devlete ya da ulusa ait olma fikri (bir devlete vatandaşlık bağı ile bağlanma), milli devletin yaşamında temel kurucu bir unsurdur. Milliyetçiliği ve onunla beraber gelişen milli devletleri eski rejimlerden ayıran en önemli unsurlardan biri de krala veya feodal beye duyulan sadakatin bir inanç biçimi olarak inşa edilmiş bir millete ve o millet adına güç kullanan devlete sunulmasıdır. Son tahlilde milliyetçilik ulus devleti talep eder. Ulus devletin kuruluşu ise milliyetçiliği kuvvetlendirir. Bu yüzdende bu iki kavram birbirleriyle karşılıklı bir etkileşim içindedir. (2008, s. 8-11)

Gellner’a göre ulus ve devlet birbirinden bağımsız ve ayrı süreçlerde oluşmuşlardır. Devlet kesinlikle ulusun yardımı olmadan ortaya çıkmıştır. Bazı uluslar da devletin inayeti olmadan ortaya çıkabilmiştir. (2013, s.73) Ulusçuluk, ulusların bir ürünü değildir ve tam tersine, ulusları meydana getiren ulusçuluktur. Ulusçuluk ölü dilleri canlandırma, geleneği icat etme ve eskiye ait bazı özelliklere vurgu yapma ile bu yeni ulusu inşa eder. (2013, s.138) Gellner’a göre milliyetçiliği ve onun ürünü olan milleti anlamak için, öncelikle modern devlete yani sanayi toplumuna bakılması gerekmektedir. Çünkü sanayi toplumunun gerektirdiği ekonomik ilerlemenin gelişmesi için gerekli nesnel-ussal dayanakların kurulmasında ve korunmasında Weber’in de işaret ettiği gibi bu ulus devlet yapısı kaçınılmazdır. Çünkü milliyetçi oluşumların alt yapısını sağladığı türdeş kültürel yapılar, özellikle ortak dil ve eğitim sayesinde sanayi kapitalizmine özgü hareketleri ve bereketli iş bölümünün gerçekleşmesi mümkün olabilecektir. Bu dönem önceki dönemden farklı olarak aileye dayalı eğitim sisteminden ortamdan bağımsız herkese açık genel ve tek bir eğitim sistemine dayanmaktadır. Bireyi modern dönemde anlamlı kılanda bu eğitim aracılığıyla verilen kimliktir. Modern insan bir krala, toprağa ya da inanca sadakat beslemiyordu, bir kültüre sadakat besliyordu. (2013, s.106) Gellner endüstri devriminin ihtiyaç duyduğu eğitimi ancak merkezi bir devletin sunabileceğini ve kültürle devleti bir araya getiren olgunun bu olduğunu düşünmektedir. Milliyetçiliğin rolü ve sırrı da burada yatmaktadır. Çünkü modern çağda her devlet meşruiyetini milliyetçi söyleme borçludur. Yine endüstrileşmenin doğal gerekliği olan türdeşliğin sağlanması ve ulus devletin güçlü bir zemine oturması da milliyetçilikle yakından ilintiliydi. Gellner, milliyetçilik bağlamında ulus devlete geçişte beş evre belirler: 1) Çıkış çizgisi: Etnik farklılıkların belirgin olmadı̆̆ı dönemdir. 2) Milliyetçi başkaldırı: Etnisite yavaş yavaş siyasal bir farklılık olarak kendini gösterir. 3) Milliyetçi başkaldırının zaferi ve kendi kendini yok ediş: Çok etnik gruplu imparatorluklar çöktüğü ve milliyetçiliğin tek siyasal meşruiyet aracı haline gelmiştir.4) Gece ve sis: Milliyetçiliğin gerekleri, özümseme gibi yöntemlerle değil, aşırı uygulamalarla kendini gösterir (bu terim özellikle Nazi Almanya’sı için kullanılmıştır). 5) Endüstrileşme sonrası: Milliyetçiliğin eski şiddetini kaybettiği ve refah devlet anlayışının hâkim olduğu dönemdir. (Özkırımlı, 2015, s.164-165)

Milliyetçiliği modernleşmenin bağımlı değişkeni olarak gören bir diğer isim de Karl Deutsch'dır. (Öğün, 2000, s.70-72) Ulusların inşa edildiğini savunan Karl Deutsch, bir ulusal topluluğun, üyeleri arasındaki karşılıklı ilişkinin yoğunluğuna dayandığı görüşünü öne sürer ve söz konusu etkileşimin sanayi toplumunun ürünü; şehirleşme, gazete-kitap okuma, nüfusun sektörel dağlımı gibi olgulara dayalı olduğunu ifade eder. (Özkırımlı,2015, s.62) Benedict Anderson da bu görüşü 
destekleyerek, kitap yayıncılığının ve bu suretle ortaya çıkan yayın dillerinin önemini vurgular. $\mathrm{Bu}$ yolu açan temel etken olarak ise kapitalizmi görür. (2014,s.52) Anderson’a göre, matbaanın icadının, ulus devlet ve milliyetçiliğin anlam dünyasının oluşmasında oldukça önemli bir etkisi vardır. Bu icat, gazete, roman gibi yazılı kaynakların toplumsal yaygınlık kazanmasına ve bu yayılmanın sıradan insanların anlam dünyası üzerinde "kolektif" etkiler yaratmasına neden olmuştur. Belli tarzda bir düşünme biçiminin yarattığı bir anlam dünyası ve zihniyet yapısı milliyetçi düşünceye kaynaklık etmiş, ulusun bir düşünce sistematiği içerisinde kurgulanmasının önünü açmıştır. (2014, s.54-56)

Anderson'da milletler ve milliyetçilik özel bir kültürel yapımdır. Bu yapımları anlayabilmek için tarih içinde ne zaman ve nasıl doğduklarını ve bugün için yoğun bir duygusal meşruiyete nasıl sahip olduğunu çözümlemeliyiz. (Özkırıml,2015, s.176) Anderson’a göre millet hayal edilmiş siyasi bir topluluktur. Bunlar öylesine konumlandırılmışlardır ki en küçük milletlerin üyeleri bile birbiriyle temas etmeksizin birbirleri hakkında bir duyguya sahip olacaklardır. (2014, s.6) Dinin bu dönemde önemini yitirmesine değinen Anderson hayata anlam katacak bir duygu olarak hayali cemaatleri işaret eder. Anderson’a göre, ölümlülügü sürekliliğe çevirecek, rastlantıya anlam katacak daha seküler bir form olarak millet sonsuz bir geleceğe halkı sürükleyebilmektedir. Milliyetçiliğin büyüsü bu açıdan rastlantıyı kadere dönüştürmesinde yatmaktadır. (2014, s.12) Ulusu kendisine aynı zamanda hem egemenlik hem de sınırlılık içkin olan "hayal edilmiş" bir cemaat olarak tanımlayan Anderson’a göre, ulus sınırlı olarak hayal edilir, çünkü bir milyardan fazla insanı kapsayan en büyügünün bile, ötesinde başka uluslara mensup insanların yaşadığı, esnek de olsa sonlu sınırları vardır. Yani, hiçbir ulus kendisini insanlığın tümü ile örtüşüyor olarak hayal etmez. İkinci olarak, ulus egemen olarak hayal edilir, çünkü kavram, Aydınlanma ve Devrim’in (Fransız Devrimi), ilahi olarak buyrulmuş, hiyerarşik hanedanlık mülklerinin meşruiyetini aşındırmakta olduğu bir çağda doğmuştur ve ifadesini egemen devlet kavramında bulmaktadır. Son olarak, ulus bir topluluk, bir cemaat olarak hayal edilir, çünkü her ulusta fiilen geçerli olan eşitsizlik ve sömürü ilişkileri ne olursa olsun, ulus daima derin ve yatay bir yoldaşlık olarak tasarlanır. Son iki yüzyıl boyunca milyonlarca insanın, birbirlerini öldürmekten çok, böylesi sınırlı hayaller uğruna ölmeye razı olmalarını mümkün kılan şey, son kertede bu kardeşliktir. Örneğin meçhul asker veya anitlar bu hayallerin sembolize edilmesini ifade etmektedir. (2014, s.22-23)

Özellikle milliyetçilik kuramında özsel (ilkçi) yaklaşımı savunan ekole göre ulusların icadı sorunlu bir yaklaşımdır. Çünkü onlara göre etnisite doğuştan kazanılan bir durumdur ve sonradan üretilmesi olanaksızdır. Özsel görüş bu açıdan tarihselci görüşün modernizm öncesi dönemin sosyo-kültürel birikimini yok sayması noktasındaki eleştiride haklı olmakla birlikte; milliyetçiliğin modern dönem ulus devletin önemli bir bileşeni olduğu ortadadır. Bu kapsamda özellikle 19. ve 20. yüzyılda ortaya çıan ulus devletlerde gözlemlenen yeninin üretimi üzerinden kimlikler inşası bağlamında inşacı ekol önemli argümanlara sahiptir. Ancak özellikle günümüz milliyetçi akımları açıklamada bu tez tek başına yetersiz kalmaktadır. Yine ulusların milliyetçi kazanımlarının sadece bir hayal veya icat olarak tanımlamakta ekonomik temelli yaklaşımda düşülen indirgemecilik tehlikesini de içinde barındırmaktadır. 


\section{Ulus Devletin Oluşumunda Sosyo-Kültürel Temelli Yaklaşım}

Uluslaşmayı siyasal olmaktan ziyade sosyolojik bir olgu olarak ele alan Türkdoğan’a göre; "Milletleşme ve millet oluşturma, tarihi gelişim çizgisi içinde, toplamsal bir süreçtir. Bu nedenle, geniş çapta sosyal yapıyla bağlantılıdır. Şöyle ki; toplumların bir evrim çizgisi vardır. Bu da klan veya hord diye ifade edilen en ilkel toplum tipinden günümüz millet kuruluşuna kadar ilerleyen bir yapısal değişme sürecini yansıtmaktadır”. Ardından ulus tanımını yapan Türkdoğan’a göre, ulus; kabile-aşiret ve feodal yapıdan daha üst düzeyde donatılmış bir üst kuruluşa yükselişin son safhasını ifade etmektedir. (1995, s.8) Bu noktada, diğer bir sosyo - kültürel değişiklikte iktidarın sekülerleşmesinde görülmektedir. Bu yönüyle Weber ulus devleti, ulusun iktidarının dünyevi örgütlenmesi olarak tanımlar. (Schulze,2005, s.195) Weber modern devletin dinden devraldığ 1 bir özelliğe vurgu yapar; bu ölüme anlam katmaktır. Weber’e göre modern devlette bu işlevi dinin yerine yurttaşlık bilinci almıştır. Bu bilinç bir topluluğun ve seküler bir hedefin motive ettiği aidiyet hissi ile birçok genç erkeği büyük bir istekle savaş alanlarına sürüklemiştir. (Poggi, 2005, s.121)

Milletin oluşturduğu duygusal etkinin coşkusu ekonomik bir kökenden ziyade, iktidarın tarihsel kazanımındaki küçük burjuva kitlelerinin saygınlık düşüncelerine dayanır. Bu siyasi saygınlık gelecek nesillere karşı sorumluluk bilinciyle birleşir. Etnik bağlılığın tek başına bir ulus oluşturamayacağını söyleyen Weber, bir ulusun oluşmasında kültürel öğelerin daha önemli olduğunu savunur. Kılıçbay bu farkı açıklarken, ulus ile etnikliğin aynı şey olmanın ötesinde birbirilerinden çok farklı tarihsellik ve toplumsallıklara denk düştüğünü, etnisitenin insanların bilinçli iradelerinin dışında biyoloji ve tarih tarafından oluşturulan bir toplumsallık olduğunu ifade eder. Başka bir deyişle, etnisite, kader sayılan yerellikten başka bir şey değildir. Ulus ise, bunun tersine tarihsel bir inşadır. Tarihin belli bir konağında ve belli bir mekânda belirtilmiştir. İnsanların iradi gayretlerinin ürünüdür, doğanın dayatması sonucu değil, düşünsel faaliyetler sonucu ortaya çıkmıştır. (Max Weber'den aktaran; Kılıçbay, 1996, s.90-91) Bu doğa dışı süreci biyo-siyasal politikalar olarak tanımlayan Taburoğlu ise halkı biyo-siyasal uygulamaların bir sonucu olarak şekil verilmiş bir yığın olarak betimler. Halkın siyasetle birlikte dünyevi bir zemine çekilmeye başladığı modern zamanlarla birlikte ortaya çıkan boşluk bu biyo-siyasal uygulamalar kullanılarak doldurulmuş ve halk disiplin altına alınmıştır. Böylece "halk" biçimsiz bireylerden, ödevlerini bilen politik yurttaşlara dönüştürülmüştür. (Taburoğlu, 2008, s.32-33) $\mathrm{Bu}$ yaratıma öncülük eden temel dinamik ise milliyetçilik olmuştur. Modern dünyanın birey odaklı anlayışının ortaya çıkardığı hazcılık milliyetçiliğin yarattığı maneviyatla dizginlenmiş ve toplumsal fedakârlıklar için gereken ideolojik temeli hazırlamıştır.

Weber, ulus devletin gelişimi modern zamanlarda tamamlandığından, onu modern kavramlarla tanımlamanın daha doğru olacağını savunur. Bu açıdan modern devlet; yasaları değiştirebilecek idari ve hukuki düzene sahiptir ve hükmettiği tüm alanlarda nihai söz sahibidir. Resmi güç kullanma kudretine sahiptir. Weber'e göre millet ve ona bağlı olarak kurumsallaşan modern ulus devleti ortaya çıkaran etmenlerin başında ortak siyasi yazgılar gelir. (2014, s.44) Bazen aslında heterojen olan halklar siyasal olaylar sonucu homojen bir tavır ile aynı kader tarafından 
şekillendirilirler. Bu yüzdende millet her şeyden önce bir paylaşım, bir değerler ve inançlar toplamıdır. Bu inancın öznesi olan yurttaş ise, yurttaş olma bilinci ve bir topluluğa ait olma düşüncesi ile eski rejimden ve onun kulluk anlayışından sıyrılarak yeni bir egemenlik modelini de inşa etmiştir. Fransız devrimi boyunca ortaya çıkan yurttaşlık bilinci bu yönüyle sınırsız iktidar anlayışının karşısındadır. Sonuç olarak, modern devlet, ulus devlete sıkıca bağlı olduğu gibi yurttaşlıkta ulus devlete bağlı bir kavramlaştırmadır. (Touraine, 2011, s.100)

Ulusu ve ulus devlet kavramlarını birbirinden ayırarak işe başlayan Anthony Giddens’a göre, ulus, ancak bir devlet egemenliğini iddia ettiği bölge üzerinde birleşik idari erişime sahip olduğunda mümkündür. Modern dünya kapitalizm, endüstriyalizm ve ulus devlet sisteminin kesişmesi ile şekillenmiş̧tir. Buna göre kapitalizm, bir devlet sistemi ile ilişki içinde ortaya çıkmıştır. Avrupa devlet sistemi, hem kapitalizmin ayrı bir üretim tarzı olarak ortaya çıkmasının önkoşullarını sundu hem de kapitalizm ile devlet sistemi arasındaki karşılıklı ilişkiler, Avrupảnın 16. yüzyıldan itibaren dünyanın geri kalan kesimi üzerinde artan egemenliğini güvence altına alan bir araç haline geldi. 19. yüzyllda sanayi kapitalizminin gelişmişliği yalnızca bir ulus devletler sistemi içinde yer alan Avrupa devlet sistemi ile örtüşmekle kalmadı, aynı zamanda doğası gereği onunla ilişki içinde oldu. Ulus devletlerin kurulmasıyla birlikte tebaadan vatandaşa geçilen süreçte artık bireyin devlete ve topluma karşı sorumlulukları olduğunu söyleyen Giddens; artık suç işleyen bir kimse asi değil; toplumun genel kurallarına aykırı davranan anomik bir durumun temsilcisidir. (2008,s. 129-134)

A.D. Smith, Avrupa'da ulus devlet kurma süreçlerinin modern devletin ortaya çıkmasıyla beraber görüldügünü ve Amerikan ve Fransız devrimleri sonunda bu modelin hâkim organizasyon şekline geldiğini söyler. Buna göre ulus devlet yapılanmasının beş temel özelliğinden bahseder: 1) Ulusun esasen territoryal politik bir topluluk olduğu, 2) Ulusun, üyelerinin ilk politik bağını ve baş sadakatini oluşturduğu, 3) Ulusun, yurttaşların bir inşası olduğu ve bunda özellikle liderlerin ve elitlerin rol oynadığı, 4) Ulusun, sosyal ve politik gelişmenin en belirleyici unsurunu oluşturduğu. (2014, s.182-185) Bu kavramlaştırmadan anlaşılacağı gibi, ulus devletler bu süreçle birlikte merkezileşmiş ve kendi içinde homojenleşmişken, diğer devletlere göre ayrışan ve farklılaşan yeni devletler düzeninin oluştuğunu ve bu devletlerde meşruiyetin kaynağını ulusun oluşturduğunu görüyoruz. Milliyetçiliğin beş değişik işlevinden bahseden Smith ilk sıraya milletleri kurma ve ulus devletleri ayakta tutma işlevinden bahseder. (Özkırımlı, 2015, s.219) Smith'in temel kaygısı ulus devlet yapılanmasından ziyade, milletlerin oluşumuna yönelik olsa da bu noktadan hareketle ulus devlet kurma süreçleriyle millet kurma süreçleri arasındaki modern paralelliği göstermesi açısından çalışmaları önemlidir.

Hagen Schulze’e göre, İngiltere'de şanlı devrim, Fransảda 1789 ihtilalinin yol açtığı karışıklıktan sonra, halkın yönetim süreçlerine doğrudan ya da plebisit aracılığılla katılma oranı sürekli artmıştır. Diğer bir değişle aristokratların ulusundan halkın uluslarına geçilmiştir. Bu akım kısa sürede Avrupảnın geri kalanında izlenecek yolu da belirlemiştir. Viyana kongresinde Avrupảnın geleceği tartışmalarının öncelikli konusunu da oluşturacak ulus devlet yapılanması 
hakkında hevesli olanlar kadar ciddi şüpheleri ${ }^{3}$ olanlar da mevcuttu. Ancak ulus devlet fikrinin, Avrupa’nın modern çağa giden yolda, mantıksal açıdan en iyi seçim olacağı açıktır. Çünkü bireylerin sürekli artan oranda yükselen siyasal katılım talepleri ulus ve demokrasi arasında bir ilişkiyi de beraberinde getirmiştir. Bu yönüyle ulus devlet demokrasi ve parlamentoların garantörü olan bir devlet sistemi olmuştur. Avrupa’da ulus devletlerin gelişimini coğrafi olarak üçe ayıran Schulze Batı Avrupa(İngiltere ve Fransa)'da ulus devletlerin gelişiminin kurucu role sahip olduklarını ve kendilerinden sonraki uluslaşma süreçlerine rehberlik ettiklerini savunur. Örneğin Hollanda İngiltere'deki gibi evrimci bir yolla bu işe girişirken; İspanya, Fransa'dakine benzer şekilde devrimci yani; bir ulusun devletin ulusal anayasasıyla beraber kurulması tarzında bir ulus devlet kurma sürecine girer. Bu Batı Avrupa ülkelerinde diğer Avrupa coğrafyasından farklı olarak genellikle monarşiler gücünden feragat ederek gerçekleşmiş ve ulus devlet içinde tarihsel bir sembol olma rolü üstlenmiştir. (2005, s. 201-202)

Orta Avrupa'da ise durum tamamen farklıdır, burada Almanya ve İtalya büyük bir siyasal parçalanma içinde küçük şehir devletçiklerinden meydana gelen bir yapıya sahiptir. Schulze bu yapının tesadüfü olmadığını ileri sürer. Schulze’e göre bu, Avrupa’da yüzyıllarca korunan dengenin bedelidir. Çünkü bu bölge barış zamanı diplomatik bir düzlük savaş zamanı ise operasyonların gerçekleştiği savaş alanı idi. Ayrıca bu bölgeyi kontrol eden merkezi bir devlet Batı Avrupa için büyük bir tehdit oluşturmaktaydı. Bu yüzden İtalyan ve Alman devletlerinin bağımsız yapısı, Avrupa devletler dengesinin garantisi olarak görülmekteydi. Tüm bu nedenlerden ötürü ulus devlet kurma süreçlerini ancak 1870’li yıllarda tamamlayan bu iki devlet, özellikle Almanya'da Alman romantik milliyetçiliğinin itici gücüyle bu süreci tamamlamıștır. Doğu Avrupa'da ise ulus devlet fikri mevcut siyasal sistemle tam anlamıyla karşıtlık içindeydi. Kıtanın genelde Slav olan doğusu, ne tek uluslu anayasal ilkelere bağlı devletlerden, ne de orta Avrupa'daki gibi küçük devletlerden oluşmaktaydı. Bu bölge imparatorlukların kontrollünde tarihsel bir belirsizlik içinde varlıklarını sürdüren yığınlardan ibaretti. O yüzden buradaki milli devlet kurma hareketleri aynı zamanda özgürlük hareketleri olarak düşünülmekte ve self determinasyon hakkına dayandırılmaktaydı. Schulze’e göre, ulusların kökenlerinin hep savaşlar oluşturmaz ama çoğu zaman katalizör vazifesi görür. Avrupalıların kendi kimliklerini keşfetmede ilk andan itibaren etkili olan şeyin komşularıyla olan sınır çatışmaları ve bu sınırlar için yapılan savaşlar olduğunu kabul eder. Sonuç olarak Schulze, ulus devletlerin modern çağdaki kültürel toplumsal değişkenlerin etkisinde artan savaş baskısı çerçevesinde tarihsel bir kaçınılmazlık olarak ortaya çıktığını savunur. (2005, s. 203-204)

Lipset ve Rokkan ise toplumu "merkez-çevre" ekseni ve "işlevsel” eksen olmak üzere iki ana eksene bölmüş, toplumun bu karşıtlıklar üzerinden kutuplaşarak, siyasal konumunu aldığını savunmuşlardır. Ancak aynı zamanda merkez, çevresel öğelerle bir bağlantılar sistemi içerisinde

3 Friedrich Von Gentz Viyana Kongresinde Şöyle Diyordu: “Almanya’nın tek devlet olarak var olmasını çok tehlikeli görerek: tüm Alman kabilelerinin tek ve bölünmez bir devlet olarak var olması binlerce yıllık kazanımların bir kenara koyulması olarak gören Gentz, ayrıca böyle bir devletin ortaya çıkması halinde; gelecek nesillere kalacak olan tek şeyin kalıntı yıkıntılardan oluşan çorak bir düzlük olacağını söyler.” (Bknz. Schulze, H. (2005). Avrupa'da Ulus ve Devlet. (Çev. T. Binder). İstanbul: Literatür Yayınları.195-196) 
bulunmaktadır. Örneğin; orta çağın büyük zümreleri (estates) parlamentolarda yer almış, alt sinıflara haklar tanınmıştır. Dolayısıyla modern devleti yaratan merkezileşme süreci, dayandığı feodal temeller sebebiyle, merkezin çevre ile uzlaşmalar yapmasını zorunlu kılacak çatı̧maları içermektedir. Ulusal elitlerle yerel güçler, üretim faktörlerine sahip olanlarla ol(a)mayanlar, devletle Kilise gibi unsurlar arasındaki gerçekleşen bu karşı karşıya gelmeler, ortaya çıkan ulus devletin iyi eklemlenmiş bir yapıya sahip olmasını olanaklı kılmıştır. Güçler arasındaki çatışmalar ne zaman bir uzlaşma ile sonuçlansa çevrenin bir bölümünün merkeze eklemlenmesi sağlanmış olmaktadır. Dolayısıyla Avrupada siyasal kimliklerin ortaya çıkmasında etkili olan sosyal çatışmalar (kültürel-ideolojik ve ekonomik) şu alanlarda belirginleşmiştir: 1) Merkez-Çevre çatışması, 2) Devlet-Kilise çatışması (laiklik ve eğitim sisteminin kontrolü), 3) Şehirli-Köylü çatışması (ekonominin birincil ve ikincil fertleri arasında), 4) İşçi-İ̧veren çatışması (üretim faktörleri arasında, emek - kapital). (Lipset and Rokkan, 1967, s.10-14)

Rokkan teorisi öncelikle milli devletlerinin kuruluşu üzerinden açıklamaya çalışmakta ve 17. yüzyıldan itibaren Avrupa’da gelişen kavramları incelemektedir. Ekonomik değiş̧kenleri önemsemekle birlikte Rokkan, territoryal değişiklikleri özellikle vurgulamaktadır. Buradaki territoryal özellik, belirli bir siyasal merkezin sahip olduğu askeri ve idari güç sayesinde çevreye giderek hâkim olmasını ifade etmektedir. Kültürel değişkenler ise bu noktada heterojen olan halkın homojenleşmesinde önemli araçsal bir rol oynamaktadır. Din ve dil gibi kültürel değişkenler yeni oluşan siyasal sistemde merkezin siyasal birliğinin oluşmasına katkı sağlamaktadır. $\mathrm{Bu}$ açıklamadan anlaşılabileceği gibi Rokkan Marksist araştırmacıların ekonomik determinizminin aksine siyaset merkezli bir devlet kurma sürecinden bahseder. Bu modelde siyaseti belirleyen öge bizatihi siyasetin kendisidir. Rokkan bu noktadan hareketle ekonomik-kültürel bir temellendirmeyle doğu - batı farklılaşmasını açıklamaya çalışmaktadır. Ekonomik olarak, kent ekonomisinin Avrupa'da tesis edilmiş olması ulus-devletin oluşumuna yol açtığını; doğuda ise tarıma dayalı ekonominin bir sonucu olarak bürokrasi temelli ve toprak aristokratlarının icazetiyle oluşturulmuş yapılar kurulmuştur. Bu noktaya kadar ekonomi temelli yaklaşım ile aynı doğrultuda ilerleyen Rokkan, kültürel faktörleri analizine dahil ederek farklılaşır. Buna göre, coğrafi olarak kuzey ve güney eksenli bir yaklaşımla Avrupảda kültürel farklılıkların devlet kurma süreçlerini nasıl etkilediğini göstermeye çalışmaktadır. $(1975$, s. 6)

Bu noktada dini modelini açıklamak için kullanan Rokkan’a göre; kuzey, reform hareketlerinin vatanı iken; güney Katolik Kilisesi ve karşıt reform hareketlerinin mevzilendiği topraklardır. Kuzeyde bu yönüyle reform hareketleri uluslaşma sürecine önemli katkı yapmıştır. Güneyde ise Kilisenin etkisinde, başlıca işlevi ümmet duygusunu aşılamak olan bir yapının etrafında uluslaşmanın gelişmesini engelleyen siyasal ve sosyal bir alan oluşmuştur. Gerçekten de Rokkan özellikle İtalya ve Almanyảnın uluslaşma sürecinin geç gerçekleşmesinde dinin kaynağı olarak Vatikan’n etki alanına yakın olmasını gösterir. Yine İngiltere'de ilk uluslaşma emarelerinin görülmesini Vatikan ile ilişkilerin çok gevşek olmasına bağlar. Uhrevi bir iktidar kaynağından uzakta olan Portekiz, İspanya ve İsveç gibi ülkelerde de milli bilincin daha erken gözükmesini bu teoriye örnek olarak gösterir. Reform hareketlerinin işlevini anlatan Rokkan bu hareketleri, Katolik Kilisesi’nin evrenselci iddialarını reddederek, toprak bütünlüğüne bağlı, sınır saptama 
üzerinde temellenen ilk devletlerin kurulmasına imkân sağlayan sürecin tetikleyicisi olarak görmektedir. Ulus devlet kurma süreçlerinde tarihsel süreçlerin önemine vurgu yapan Rokkan, kent devletlerinin siyasal yapısının, Almanya ve İtalyada ulus devlet kurma sürecini etkilediği görüşündedir. Özellikle Roma İmparatorluğu mirasının etkilerini önemseyen Rokkan kent devletlerinin aksine otoriter monarşi geçmişi olan Fransa, İspanya gibi ülkelerde ulus devletin daha erken kurulduğuna işaret eder. (Vergin, 2015, s. 222-225)

Rokkan ulus devletin kurulma sürecini dört aşamada sunar: Birinci aşama, 15. yüzyıldan Fransız Devriminin yapıldığı 18. yüzyıla kadarki süreyi kapsar ve devletin oluşumunu içerir. Bu aşamanın ortaya çıkardığı en önemli sonuç, seçkinler düzeyinde ekonomik, siyasal ve kültürel açıdan bütünleşmenin gerçekleşmesidir. Kandaşlık ve yerellikten uzaklaşılarak ulusal pazar çerçevesinde birleşilmesi sürecinin öncüleri durumundaki seçkinlerin yerel egemenliklerini terk ederek diğer egemenlerle gerek ekonomik düzeyde birleşmesi gerekse siyasal ve kültürel düzeyde diğer yerelliklerden gelen seçkinlerle yeni bir takım kural, ilke ve değerler çerçevesinde bütünleşmesi. İkinci aşamada ise, kitlelerin giderek artan oranda sisteme dahil olmasını ifade eder. Bunda asker ocağının, okulun, yeni kitle iletişiminin ve merkezin seçkinleri ile kenar arasında teması sağlayan kanalların oynadığı rol etkili olmuştur. Bir diğer önemli etken ise, aynı kanalların kitleler nezdinde yarattığı yeni kimlik duygusudur. Bu yeni kimliğin Kiliseler, mezhepler veya yerel seçkinler tarafından yaratılmış olan egemen kimlikle çatışma içine girmesi, ikinci aşamanın ortaya çıkarmış olduğu önemli sonuçtur. Ulusal pazar çerçevesindeki birleşmeye katılmayan yerel egemenlerin veya eski üretim biçiminin faydasını görmeye devam eden din adamları ile mezhep, tarikat vs. gibi dinsel önderlerin sürdüre geldikleri statüye dayalı hiyerarşi anlayışı ve buna dayalı olarak egemenliğini sürdüren yerel seçkinlerin de çıarlarını savunun eski kimliklerin, bu yeni kimlikle çatışması kaçınılmazdır. Türk modernleşmesi bağlamında bu kimlik çatışmasına baktığımızda, ulusal pazar için üretim yapılan endüstri merkezlerine giden köylünün köyünde iken bağlı olduğu ağa, şeyh, dede gibi yerel dinsel figürler ile feodal önderin belirlediği eski kimliklerin, modernleşme bağlamında Türkiye’de yurttaş olarak ortaya çıkan yeni kimliklerle uzun süren çatışmasını açıklamaktadır. Yine örneğin ulusal pazar için üretim yapan endüstri merkezlerinde üretim yapan bir işçi, köyünde yaşarken, dede denilen ya da şeyh denilen dini lidere verdiği ödentiyi şehirde sendikaya verecektir. Kendisine yılın belli dönemlerinde maddi katkı sunma durumundaki tebaasının, kente gitmesi ile bu gelirden yoksun kalan, ağa, şeyh, dede gibi yerel önderlerin kendisine katkı sağlayan eski kimliğinde ısrar edip yeni kimliğini kabul etmeyeceği açıktır. Ancak yeni sistemde dünün köylüsü yani feodal yapının üreticisi, mezhep, tarikat mensubu artık ulusal pazara üretim yapan bir fabrikanın işçisidir. Bu da bu sürecin tersine döndürülemeyecek bir noktaya geleceğini ve direnen kesimleri de sürece dahil edileceğini göstermektedir. (1975, s. 570-571)

Üçüncü aşamada, toplum üyelerinin siyasal sistemin işleyişinde tebaa anlayışından aktif yurttaş kavramına geçişini anlatır. Bu aşamada, değerlere dayanan yerel çatışmalardan, daha çok çıkarlara dayalı işlevsel çatışmalara geçilmesi bir diğer önemli değişimdir. (1975, s. 571-572) Bu aşama bir önceki aşamadaki çatışmaların ciddi bir biçimde sonuçlandığı aşama olarak yorumlanabilir. Pazar için üretim yapmak üzere kırsal yapıdan üretim merkezlerine, kentlere gelen birey, eski 
değerlere dayalı çatışma yerine kendi kişisel çıkarları doğrultusundaki çatışmalarla yüz yüzedir. Yeni geldiği yerde, eski yerinden kopmuş olan eskinin köylüsü, yeninin kentlisi, işçisi artık eski ilişkilerini aşmış ve yeni kurduğu ilişkileri doğrultusundaki mücadelesinde ciddi bir kazanım aşamasına ulaşmış durumdadır. Gücünü ağasına, şeyhine, dedesine karşı değil devletine karşı kullanmak aşamasına ulaşmıştır. Dördüncü aşama, devletin idari aygıtlarının genişletilmesine ilişkin süreci kapsar. Bu aşamada yeniden dağıtım araçlarının artması; kamu refahını sağlamaya yönelik hizmetlerin genişletilmesi, ulusal çaptaki ekonomik koşulları eşitlemeye yönelik politikaların uygulanması, (müterakki vergileme, zengin sınıflardan ve bölgelerden fakir sinıflara ve bölgelere kaynak aktarımı gibi) devlet nüfuzundaki artışın göstergeleri olmuştur. Bu aşamada artık yurttaşların meydana getirdiği devlet gerçekleşmiştir. Bu aşamada işçi sınıfının talepleri politikaları belirlemeye ve hükümetleri etkilemeye başlamıştır. Yani emek kesimleri; yurttaşlığın oluşumunda etkili olduğu hükümet biçimi ile devlet anlayışı ve yeniden dağıtım araçlarının gelişip genişlemesine destek olmuştur. (1975, s.572) Özetle Rokkan’nn sınıflandırmasında, birinci aşamaya, merkezi ve yerel elitler arasındaki çatışmanın yumuşaması; yerel kimliklerin yerini aşama aşama, insanları sisteme sadakat duymaya ikna eden merkezi ve türdeş bir kimliği oluşturmaktadır. Bu kimlik kitlenin yine aşama aşama politik katılım yeteneği kazanması ve sistemden talepte bulunmasını sağlamaktadır. Son aşama olarak da dağıtım mekanizmalarının yeniden şekillenmesine yönelik eşitlik taleplerinin ortaya çıkması ile ulus kurma süreci tamamlanmaktadır. (Öğün,2000, s.73-74) Rokkan’’n bu sınıflandırmasını sırasıyla merkezileşme, standartlaşma, katılım ve yeniden paylaşım süreçleri olarak özetleyebiliriz.

Bu yaklaşım özellikle toplumsal ve siyasal süreçlerin ulus devletin oluşumunda oynadığı role vurgu yapmaktadır. Smith, Giddens ve Schulze gibi birbirinden farklı ekollerden gelen ama sosyokültürel dinamiklerin rolüne işaret eden yazarlar milliyetçilik ulus devlet ilişkisini ve ulus devleti meydana getiren tarihsel süreçleri diğer iki yaklaşıma göre daha kapsamlı ve anlaşılır şekilde açıklamaktadır. Bu yaklaşımın en önemli temsilcisi ise ulus devletin kuruluşunu dört aşamada açıklayan Rokkan'dır. Bu aşamalar Avrupa'da ulus devletlerin ortaya çıkışını açıklamaktadır. Ancak bu teori Avrupa merkezli yaklaşımı ile Avrupa dışındaki uluslaşma ve devletleşme süreçlerini göz ardı etmekte ve coğrafi olarak sınırlı bir yaklaşım sunmaktadır.

\section{Ulus Devletin Oluşumunda Askeri Temelli Yaklaşım}

Ulus devletin oluşumuna ilişkin bir diğer yaklaşımda orduyu, askeri gelişmeleri ve savaş baskısını merkeze alan görüştür. Bu görüşe göre ulus devletleri meydana getiren tarihsel süreçler savaşların ekonomik, sosyal ve siyasal yansımalarının etkisi altındadır. Bu kapsamda Franz Oppenheimer ulus devletin iş bölümünün veya uzmanlaşmanın bir sonucu olarak değil, fetih ve savaşlar yoluyla artan sosyal ve siyasal baskıların sonucu doğduğunu ileri sürmüştür. Charles Tilly de modern devletin esas itibarıyla bir savaş aygıtı olarak ortaya çıktığını ve bu işlevin gereklerine göre örgütlendiğini ve devletin kurumlarının buna göre belirlendiğini ifade etmiştir. Murray Rothbard ise ulus devleti bir toplum sözleşmesi ürünü olmaktan ziyade, fetih, savaş ve sömürüyle beraber doğduğunu iddia etmektedir. (http://www.liberal.org.tr/sayfa/ 
cemaat-cemiyet-ve-ulus-devlet-mustafa-erdogan,352.php) Bu savaşlar sonucunda toplumun tek bir ideal etrafında bir ideolojiye duygusal olarak bağlamlanmasında katalizör rolünü ise milliyetçilik oynamıştır.

Ulus devletin askeri temelli oluşumunu öne sürenlerin en önemli temsilci Tilly'dir. Tilly, Rokkan’nn öğrencisi ve yöntemsel olarak onun takipçisidir. Ancak Tilly ulus devletin oluşumunda savaş ve savaşın etkisi üzerine çalışmasını yoğunlaştırır. Avrupa'da 990 ila 1990 tarihleri arasındaki siyasi dönüşümleri inceleyen Tilly, 990’ lı yıllarda Avrupa diye bir olgudan bahsedemeyeceğimizi, Avrupa’nın daha sonraki süreçte tarihsel olarak kurumsallaştığı ifade eder. Avrupada milli devletin yükselişini 16. yüzyıldaki gelişmelere dayandıran Tilly; 1648 Vestfalya Antlaşması ile Avrupa devletler sisteminin temelinin atıldı̆̆ını söyler. Bu yeni devletler artık imparatorluklar ya da şehir devletleri biçiminde örgütlenmekten uzaktır. Bu eski sistemlerin yerine merkezileşmiş, sınırlı, belli ve halkları üzerinde denetim kabiliyetleri gelişmiş milli devletler almıştır. Tilly’e göre, ulus devletler, halkın çok güçlü bir şekilde dil, din ve semboller birliği çerçevesinde kimliklerin paylaşıldığ̣ yapılardır. (Vergin, 2015, 227) Milletin ve milliyetçiliğin teşekkülünde "diğeri” veya “öteki”nin oynamış olduğu rolü, “Devlet Öncülüğünde Milliyetçilik” ve “Devlet Kurmaya Yönelen Milliyetçilik” şeklinde kategorize eden Tilly, iki ayrı milliyetçilik türünün farklı karakterler kazanmış devletlere ve sonuçlara yol açtığını söylemiştir. Tilly belirli bir devlet üzerinde kolektif denetimi bulunmayan bir topluluğun temsilcilerinin, ayrı bir siyasî statü, hatta ayrı bir devlet talebiyle ortaya çıktığı veya daha açık anlatımıyla, dağınık bir topluluğu belirli bir devlet altında birleştirmeye ve bir millet inşa etmeye yönelen milliyetçilikler olarak tanımlanabilecek "devlet kurmaya yönelen milliyetçilik" konusunda en iyi örneklerden birisinin Batı Avrupa'da Fransa’ya karşı duyulan tepkiden beslenen İtalyan milliyetçiliğini ve daha fazlasıyla Alman milliyetçilikleri ile Türklere karşı duyulan tepkiden beslenen Balkan milliyetçilikleri olduğunu öne sürmektedir. Devlet öncülügünde milliyetçiliğe en iyi örnek ise Fransa ve İngiltere de ulus devlet kurma süreçleridir. Burada yeniden öteki üzerinden bir kimlik inşa edilmekten ziyade var olan kimlikler üst bir kimliğe devredilmek/taşınmak suretiyle ortaya çıkmıştır. (2000, s.76-78)

Tilly milli devletlerin yükselişini açıklarken iki unsura dikkat çeker. İlk olarak, İngiltere ve Fransa gibi güçlü devletlerde var olan sermaye birikiminin ve güçlü ticaretin, küçük tüccarların ekonomiye yön verdiği devletleri çökertmiş olmasıdır. Diğer faktör ise, savaş ve savaşa hazırlık için gerekli olan iktisadi kaynaklar ve örgütsel becerinin geliştirilmiş olmasıdır. Savaş gücü kapasitesi açısından denizaşırı kaynaklarında seferber edilmesiyle üstünlük bu ülkelerin savaşlardan galip çıkmasını sağlamakta ve küçük devletleri yenik düşmemek için çoğu kez gücünü aşan oranda bir savunmaya zorlamaktaydı. İşte bu savaş ve savaşa karşı mücadele bu küçük devletlerde de milliyetçiliği tetikleyen bir unsura dönüşmüştür. (2001, s.90-96) Hanedanların artık kendi adlarına savaş yapmayı bıraktıklarını söyleyen Tilly, ulusal çıkar kavramı böylece her türlü bireysel çıkarı önceleyen hakim bir anlayışa dönüştügünü vurgulamaktadır. Tilly’nin araştırmalarında önemli referans kaynaklarından birisi olan Otto Hintze'nin çalışmaları devlet oluşumu ve askeri örgütlenme arasında doğrudan bir bağ kurar. Hintze’e göre, her siyasal sistem kökeni itibariyle askeri bir sistemdir. Hintze, devlet oluşumunda ve devletin tahkim edilmesinde devletlerarası çatışmanın sınıf çatışmasından çok daha belirleyici olduğunu ileri sürer. Hintze savaşa atfettiği 
merkezi konumlandırmasını Tilly bir adım öteye taşıyarak savaş teknolojisindeki değişimin temelde siyasal sistemi de değiştirdiğini iddia etmiştir. (Vergin, 2015, s. 230)

İncelediği zaman dilimi içinde savaşma biçimi ile devlet oluşumu arasındaki ilişkiyi açıklamaya çalışan Tilly dört tarihsel aşamada sınıflandırmasını yapar. Birinci aşama (patrimonyalizm), 14. yüzyıla kadar hüküm sürmüştür, bu dönemde savaşta en önemli rolü oynayan faktör hükümdarın saldığ1 vergiler, kent milisleri ve diğer geleneksel güçlerdir. İkinci aşama (komisyonculuk) ise 18. Yüzyılın başına kadar sürmüştür. Bu dönemde, sözleşmeli paralı askerler savaşlarda öncelikli rol üstlenmektedir. Ama bu dönem boyunca esas olan, hükümdarın zengin kapitalistlerin verdiği borçlara ihtiyaç duymasıdır. Aynı zamanda hükümdar, vergi toplamada da bu zengin sınıfa muhtaçtır. Bu aşamayı Tilly "aracılık dönemi” olarak adlandırmaktadır.18.yüzyılda başlayan üçüncü dönem(ulusallaşma), kitlesel orduların ve donanmanın millileştiği dönemdir. Hükümdar silahlı kuvvetleri devletin idari bünyesi altına almaya başlamış ve aracıları vergi toplama işi de dâhil aradan çıkarmıştır. 1850'den sonraki son aşama (uzmanlaşma) ise milli devletlerin uzmanlaşmış bir kolu olarak askeri güç tamamıyla büyük bir organizasyon halini alıyor. Bu aşamada polis gücü ile askeri güç birbirinden ayrılmıştır. (2001, s.63-64) Tilly’in bu noktada vurguladığı bir diğer konuda savaşlarının amaçlarının tarihsel süreç içerisinde değiştiğidir. İlk dönemlerde savaş sonrası fethedilen topraktan fetheden devletin beklediği tek şey vergi iken zamanla karşılıklı beklentiler ve talepler değişmiştir. (2001, s.133-134)

Tilly Avrupa’da ulus devletlerin oluşumunda üç yolun öne çıtığını savunur; zor, sermaye ve zorlaştırılmış sermaye. Zor yolun kullanımı özellikle sermayenin kıtlı̆̆ı ve buna bağlı olarak şehir ve kapitalistlerin zayıf olduğu Rusya ve Macaristan gibi ülkelerde, devletler toprak sahipleri ve ruhban sınıfını iş birliğine zorlayarak, geniş bürokrasiler aracılığıyla burjuva sınıfını kontrol altına alarak kendi ulus devlet kurma süreçlerini tamamlamıştır. Venedik ve Hollanda gibi sermaye yoğun bölgelerde ise kapitalistlerin üstünlüğü askeri kuvvet oluşturmayı kolaylaştırmış ve devletin zor kullanımı olmaksızın uluslaşmasını sağlanmıştır. Bu yöntemde kapitalistlerin çıkarları gözetilerek devletin merkezileşmesi engellenmiş ve genellikle şehir devletleri biçiminde ya da federasyonlar olarak örgütlenmişlerdir. Bu iki örneğin arasında bir üçüncü yol olan ve İngiltere ve Fransa’nın temsil ettiği zorlaştırılmış sermaye yolu ise, önemli derecede toprak sahibitarımcı sermayeyi askeri kuvvet oluşturmada kolaylık sağlarken, kendi ordularını kurabilme yeteneği onlara öteki devlet türleri karşısında üstünlük getirmiş ve onları açıkça ulusal devletlere dönüştürmüştür. Bu yöntemde sermaye ve zoru elinde tutanlar eşit oranda bir ilişki kurmuşlardır. (2001, s.313-314)

Savaşların ulus devletin ortaya çıkışındaki etkisine atıf yapan diğer bir düşünür olan Michael Mann, modern ulus devleti sadece ekonomik etkenlerle ve indirgemeci bir şekilde yerel pazarların zaman içinde ulusal ekonomiye entegre olması ve piyasa çıkarlarını savunmak için devletin yeniden şekillenmesi olarak değerlendirilemeyeceğini öne sürmektedir. Mann’a göre, iktisadi gelişmelere ilişkin tespitler doğru olmakla birlikte, bu gelişmeye eşlik eden başka gelişmeler göz ardı edilmemelidir. Özellikle merkezileşme ve sınırların sabit şekil alması ile beraber devlet örgütlenmesinde ordu önemli bir alan kaplamıştır. Askere alınan insan sayısındaki artış savaşların 
paralı askerlerden ziyade yurttaşlar eliyle yapılması, ulus devletin oluşumunun temelini atmıştır. Çünkü bu gelişmeyle birlikte, kimlik duygusu taşraya ait olmaktan çıkıp ortak bir ulusa, kadere ve tarihe referans gönderen ortak bir şeye ait olmuştur. Artık yurttaş olan köylüler ortak bir kadere kanalize olmuşlardır. (1993, s.52-55) Tilly ve Mann’ın bu iddiaları özellikle sosyologlar ve siyaset bilimcileri arasında oldukça taraftar bulmuş ve 1980'lerin ortalarından itibaren savaş ve ordu, modern devletin inşası sürecinde yaşanan kurumsal değişimi etkileyen önemli bir faktör olarak kabul edilmeye başlanmıştır. (Şahin, 2016, s.89)

Sosyo-kültürel yaklaşımın tamamlayıcısı niteliğinde olan askeri temelli yaklaşım Schulze ve Giddens gibi yazarlarında çalışmalarında sosyo-kültürel etkiler başlığı altında ele alınmakla birlikte; askeri hareketler ile ulus devletin inşası arasında güçlü bağı Tilly kurmaktadır. Tarihsel perspektifte sunulan kronolojik gelişim ulus devletlerin kuruluşunu ve uluslararası aktörler olmasını farklı bir açıdan ele almaktadır. Özellikle günümüzdeki milliyetçi akımlar güncel veya yakın tarihli savaşların etkisi altındadır. Birçok farklı coğrafyada savaşlar biz ve öteki ayrımı üzerinden kimliklerin sivrilmesine ve milli duyguların ölümü anlamlı kılan bir duyguya dönüşmesine sebep olmaktadır. Bu yaklaşım özellikle Avrupa dışındaki milliyetçi akımları ve ulus devlet kurma teşebbüslerini açıklama noktasında oldukça önemli referanslar sunmaktadır.

\section{Sonuç}

16. yüzyıldan itibaren aşama aşama kendisini tarihsel bir zorunluluk olarak hâkim organizasyon şekli olarak ortaya koyan ulus devlet, sosyal ve kültürel değişimlerin hem taşıyıcısı hem de uygulayıcısı olarak günümüze kadar milli egemenlik anlayışı çerçevesinde uluslararası alanda egemen yapı olarak varlığını sürdürmüştür. Ulus devletlerin inşası Avrupa devletlerinin bütünleşmesi ve merkezileşmesi sürecinde anahtar rol oynamış ve halklarını mobilize ederek onlara birer üst kimlik etrafında hak ve ödevler bağlamında sıkı ve geçmişte görülmeyen bir bağla ilişkilendirmiştir. Modern devlet sanayi devriminin bir taşıyıcısı olarak içinde barındırdığı gerilimleri ve geçmişin kopan geleneksel ve yerel bağları yerine inşa ettiği seküler egemenlik anlayışı ve milliyetçilik çerçevesinde kendini yeni geleneklerle anlamlandırmıştır.

$\mathrm{Bu}$ sürecin tamamlanmasında feodal bağların kopması ve sekülerleşme hareketlerinin etkisi ile birlikte artan mobilizasyon ve kitle iletişim araçlarında meydana gelen değişimler de önemli rol oynamıştır. Burada önemle üzerine durulması gereken bir diğer nokta da ulus devletin oluşumunda birçok farklı sürecin oynadığı roldür. Bu çalışmada dört başlıkta kategorize edilen süreçlerden özellikle Reform hareketleri, Alfabenin çeşitlenmesi ve matbaanın yaygınlaşması, Avrupa savaşları, Ekonomik hareketlilik ve merkez - çevre ilişkisi, Vatandaşın inşası ve eğitimin kurumsallaşması gibi etmenler ulus devleti ve onun epistemolojik arka planını anlamada önem arz etmektedir.

Ulus devletin oluşumu milliyetçilikle yakından ilişkilidir. Bu ilişki bazı düşünürlerce ekonomik temelli olarak değerlendirilmiştir. Diğer bir ekol ise ulus devleti inşa edilmiş bir olgu olarak ele almaktadır. Sosyo - kültürel yaklaşım ise ulus devleti siyasal ve kültürel değişimlerin tarihsel 
bir ürünü olarak tanımlamaktadır. Son dönemde ulus devlet teorilerinde önemli bir etki oluşturan askeri temelli yaklaşım ise savaşlar ve askeri alandaki gelişmeler temelinde ulus devleti açıklamaktadır. Ekonomi temelli yaklaşım ekonomi temelli indirgemeci yaklaşımı ve süreçleri sömüren sömürülen dikotomi üzerinden anlamlandırmaya çalışması açısından kapsayıcı bir açıklama sunamamaktadır. İnşacı yaklaşım ise ulus devleti bir icat veya hayal edilmiş bir topluluk olarak açıklamaktadır. Bu yaklaşım Sanayi Devrimi sonrası süreçteki uluslaşma süreçlerini sembollere atfedilen şişirilmiş değerleri açıklamakla birlikte, son tahlilde günümüzdeki ulus devlet süreçlerini açıklamakta yetersiz kalmaktadır. Özellikle Stein Rokkan’n başını çektiği sosyo - kültürel yaklaşım ise diğer iki yaklaşıma göre daha kapsayıcı ve indirgemecilikten uzak bir açıklama sunmaktadır. Ancak bu teori Avrupa merkezli yaklaşımı ile Avrupa dışındaki uluslaşma ve devletleşme süreçlerini göz ardı etmekte ve coğrafi olarak sınırlı bir yaklaşım sunmaktadır.

19. yüzyılda artan savaş baskısı ile milletlerin varoluşsal olarak savaş meydanlarında filizlenen yönü ise hayli önemlidir. Özellikle bir hanedan için değil de bir ortak hayal olarak ulus adına savaş, savaş alanlarında da önemli başarıları mümkün kılmıştır. Bu açıdan bakıldığında milli bilincin oluşmasını sağlayan biz ve onlar ayrımının sembolleşmesi genellikle savaş alanları ve o alanların kahramanlık hikâyeleri ile ölüme modern çağda anlam katan yüksek idealler etrafında inşa edilmiştir. Bu, modern dönemin birey kavramlaştırmasının içinde barındırdığı doğal çelişkiyi; yani bireysel çıkarın toplumsal fayda için feda edilmesi, ulus devlet ile milliyetçilik arasındaki birlikteliğin açımlanmasına ışık tutmaktadır. Bu ilişki ulus devletin milliyetçilik kavramıyla kurduğu organik ilişkinin önemli bir parçasını ortaya koymasını değil aynı zamanda ulus devletin varlığını devam ettirebilmek için milliyetçilik, meşruiyet, egemenliğin doğası ve kaynağı, ortak sembollerin bireylerin motivasyonlarını etkileme süreçleri, sermaye ilişkileri ve bölüşüm gibi konuların anlaşılmasına katkı sağlamaktadır. Diğer bir deyişle bireylerin düşündükleri şey ile gerçekten oldukları şey arasında kurdukları ilişkiye ulus devletin yönetim aygıtlarının nasıl cevap vereceği güncelliğini korumaktadır.

Charles Tilly’nin kurumsallaştırdığı savaş ulus devlet ilişkisi ve bu ilişkide milliyetçiğin rolü çerçevesinde askeri temelli yaklaşım; günümüzdeki milliyetçi akımları, ulus kurma süreçlerini ve bu süreçlerin genellikle merkezinde yer alan savaşların etkisini açıklamaktadır. Birçok farklı coğrafyada savaşlar biz ve öteki ayrımı üzerinden kimliklerin sivrilmesine ve milli duyguların ölümü anlamlı kılan bir duyguya dönüşmesine sebep olmaktadır. Bu yaklaşım Avrupa dışındaki milliyetçi akımları ve ulus devlet kurma teşebbüslerini açılama noktasında oldukça önemli referanslar sunmaktadır.

Yukarıda özetlemeye çalıştığımız süreçlerden anlaşılacağı gibi ulus devletin oluşumu ve kurumsallaşması çok yönlü içsel ve dışsal faktörün etkisi altında şekillenmiştir. Ancak ortak bir payda olarak milliyetçiliğin bu süreçte araçsal bir rol oynadığ 1 aşikârdır. Ulus devlet ile milliyetçiliğin (yöntem farklılıkları olmakla beraber) bu ilişkisi dünyanın çok farklı coğrafyalarda ve kültürlerde devam etmiş ve her ulus devlet milliyetçiliğe başvurmuştur. Hatta günümüz ulus devlet sermaye ilişkilerinde öne çıkan şey ulusal kimliklerin etkin olarak kullanılmasıdır. Tek tek ulusal ekonomiler küresel piyasa tarafindan tehdit edildikleri zaman, bir yandan devletin 
ve/veya ekonominin tamamının korunmasını (yeniden bölüşümü) talep ederken, diğer yandan da ulusal kültürel kimliğe başvurmaktadır. Ancak burada ulus devleti milliyetçiliğin iz düşümü olarak anlamakta yanlış bir yaklaşım olacaktır. En başta da belirtimiz gibi devlet ve milliyetçilik birbirinden bağımsız süreçlerin ürünüdür ama tarihsel süreçte bu iki kavram ortak bir kadere sahip olmuştur. 


\section{Kaynakça}

Abdulvahap, A. (2012) Modern Ulus Devletlerin Doğuşu. Dumlupınar Üniversitesi Sosyal Bilimler Dergisi.61-70.

Ağaoğluları, M. A. (1991), Demokratik Mitoslar: Halk-Ulus Egemenliği ve Siyasal Temsil. Ankara Üniversitesi Siyasi Bilgiler Fakültesi Dergisi. Cilt: XLVI, No.1-2. 21-30.

Anderson, B. (2014). Hayali Cemaatler. (Çev. İ. Savaşır). 7.Baskı. İstanbul: Metis Yayıncılık.

Arent, H. (2016). Totalitarizmin Kaynakları-2 Emperyalizm. (Çev. B. S. Şener) 5. Baskı. İstanbul: İletişim Yayınlar1.

Balibar, E ve Wallerstein, I.(2013). Ulus Biçimi: Tarih ve İdeoloji. Irk Ulus Sınıf. (Çev: N. Ökten). 5. Baskı. İstanbul: Metis Yayıncilık.

Baumann, G. (2006), Çok Kültürlülük Bilmecesi: Ulusal, Etnik ve Dinsel Kimlikleri Yeniden Düşünmek. (Çev. I. Demirakın). Ankara: Dost Kitabevi.

Breuilly, J. (2000). Nationalism and The History of Ideas. British Academy. No:105.187-223.

Beriş, H. E. (2008), Moderniteden Postmoderniteye. Siyaset. 2. Baskı. Ankara: Lotus Yayınevi.

Bozkurt, V. (2009). Değissen Dünyada Sosyoloji.4. Baskı. Bursa: Ekin Yayınevi.

Boztemur, R. (2006). Tarihsel Açıdan Millet ve Milliyetçilik: Ulus-Devletin Kapitalist Üretim Tarzıyla Birlikte Gelişimi. Milliyetçilik I. Doğu Batı Dergisi, Sayı: 38, Yıl:9.161- 180.

Calhoun, C. (2012). Milliyetçilik. (Çev: B. Sütçüoğlu). 3. Baskı. İstanbul: İstanbul Bilgi Üniversitesi Yayınlar. Çam, E. (2005). Siyaset Bilimine Giriş. 9. Baskı. İstanbul: Der Yayıncılık.

Delannoi, G.(1998). Milliyetçilik ve İdeolojik Kataliz. Uluslar ve Milliyetçilikler. (Çev. S. İdemen.) Haz. Jean Leca. İstanbul: Metis Yayınları.

Foucault, M.(2004). Toplumu Savunmak Gerekir. (Çev. Ş. Aktaş). 3. Baskı. İstanbul: $\quad$ Yapı $\quad$ Kredi Yayınları.

Gellner, E. (2013). Uluslar ve Ulusçuluk. (Çev. B. Ersanlı - G. G. Özdoğan). 3. Baskı. İstanbul: Hil Yayıncılık. Giddens, A.(2008). Ulus Devlet ve Şiddet. (Çev. C. Atay). 2. Baskı. Kalkelon Yayınları.

Güldiken, N. (2006). Ulus, Ulus-Devlet ve Uluslaşma Kavramlarına İlişkin Tartışmalar ve T ü r k i y e . Cumhuriyet Üniversitesi İktisadi ve İdari Bilimler Dergisi, 7(2).157-168.

Habermas, J. (2002). Öteki Olmak, Ötekiyle Yaşamak. (Çev. İ. Aka). İstanbul: Yapı Kredi Yayınları.

Hobsbawm, E.J. (2014). Milletler ve Milliyetçilik. (Çev. O. Akınhay). 5. Baskı. İstanbul: Ayrıntı Yayınları.

Işıklar, C. (2008) Günümüz Türkiye’sinde Ordunun Asker alma Sisteminin Korunması Meselesi ve Millî Devlet Anlayışı ile İlgisi. Gazi Üniversitesi Hukuk Fakültesi Dergisi. Sayı: XII.797-821.

İnternet: http://www.latin-dictionary.org/natio

İnternet: Erdoğan, M. Cemaat, Cemiyet ve Ulus Devlet. http://www.liberal.org.tr//

Karatani K. (2017) Dünya Tarihinin Yapısı Üretim Tarzlarından Mübadele Tarzlarına. (Çev. A. Karatay). İstanbul: Metis Yayınları.

Karyelioğlu, S. (2012). Ulus Devlet ve Milliyetçiliğin Tarihsel Dayanakları ve Küreselleşmenin Ulus Devlet ve Milliyetçilik Üzerindeki Etkileri. Ethos Dergisi. Sayı:5(1).137-169.

Kılıçbay, M. A. (1996). Uyruktan Vatandaşa, Geçimden İktisada. Ankara: İmge Kitabevi.

Kohn, H. (2008). The Idea of Nationalism. 2. Baskı. New York: Transaction Publishers. (Ilk Yayın 1944, Toronto).

Leca, J.(1998). Neden Söz Ediyoruz?. Uluslar ve Milliyetçilikler. (Çev. S. İdemen.) Haz. Jean Leca. İstanbul: Metis Yayınları. 
Lipset, S. M, Rokkan S, (1967) “Cleavage Structures, Party Systems, And Voter Alignments: An Introduction", Party Systems And Voter Alignments: Cross-National Perspectives. New York: Free Press.

Jaffrelot, C. (1998). Bazı Ulus Teorileri. Uluslar ve Milliyetçilikler. (Çev. S. İdemen.) Haz. Jean Leca. İstanbul: Metis Yayınları.

Jeanniere, A (2000). Modernite Nedir?, (Çev. N. Tutal). Der. Mehmet Küçük, Modernite VV e r s u s Postmodernite. 3. Baskı. Ankara: Vadi Yayınları.

Mann, M. (1993). The Sources of Social Power, Volume 2: The Rise of Classes and Nation - States 17601914. Cambridge: Cambridge University Press.

Meriç, C. (2005). Mağaradakiler. 12. Baskı. İstanbul: İletişim Yayınları.

Öğün, S.S. (2000). Mukayeseli Sosyal Teori ve Tarih Bağlamında Milliyetçilik. Bursa: Alfa Yayınevi.

Özkırımlı, U. (2005). Milliyetçilik Kuramları.5. Baskı. Ankara: Doğu Batı Yayınları.

Poggi, G. (2005). Modern Devletin Gelişimi. (Çev. Ş Kurt - B. Toprak). 3.Baskı. İstanbul: İstanbul Bilgi Üniversitesi Yayınları.

Rokkan, S. (1975). Dimensions of State Formation and Nation Building: A Possible Paradigm For Research on Variations Within Europe. New Jersey: Princeton University Press.

Roskin, M. G. (2014). Çağdaş Devlet Sistemleri: Siyaset, Coğrafya, Kültür. (Çev. B. Seçilmişoğlu) 7. Baskı. Ankara: Liberte Yayınları.

Sarıbay, A.Y. (2000). Global Bir Bakışla Politik Sosyoloji. Bursa: Alfa Yayınları.

Schulze, H. (2005). Avrupa'da Ulus ve Devlet. (Çev. T. Binder). İstanbul: Literatür Yayınları.

Smith, A.D.(2014). Milli Kimlik. (Çev. B. S. Şener). 7. Baskı. İstanbul: İletişim Yayınları.

Şahin, H. (2016). Tarihsel Süreçte Savaşların Devletin Oluşumu ve Dönüşümündeki Rolü. Pamukkale Üniversitesi Sosyal Bilimler Enstitüsü Dergisi. Sayı 24, 87-101.

Taburoğlu, Ö. (2008). Dünyevi ve Kutsal. İstanbul: Metis Yayınları.

Tilly, C. (2000). Avrupa'da Devrimler - 1492-1992. (Çev: Ö. Arıkan). İstanbul: Yeni Binyıl Yayınları.

Tilly, C. (2001). Zor, Sermaye ve Avrupa'da Devletlerin Oluşumu. (Çev: K. Emiroğlu). İstanbul: İmge Yayınevi.

Touraine, A. (2011). Demokrasi Nedir? (Çev: O. Kunal). 5. Baskı İstanbul: Yapı Kredi Yayınları.

Türkdoğan, O. (1995). Niçin Milletleşme. İstanbul: Türk Dünyası Araştırmaları Vakfı Yayınları.

Uzun, T. (2003). Ulus, Milliyetçilik ve Kimlik Üzerine Bir Değerlendirme. Kimlikler. Doğu Batı Düşünce Dergisi. Say1: 23. 131-154.

Vergin, N.(2015). Siyasetin Sosyolojisi. 11. Baskı. İstanbul: Doğan Kitap.

Yıldırım, E. (2006). Küreselleşen Dünyada Milliyetçilik. Milliyetçilik I. Doğu Batı Dergisi. S a y $1: 38$, Y11:9.181-202.

Zizek, S. (2012). Yamuk Bakmak. (Çev. T. Birkan). 5. Baskı. İstanbul: Metis Yayınları.

Weber, M. (2014). Bürokrasi ve Otorite. (Çev. H. B. Akın). 7.Baskı. Ankara: Liberte Yayınları. 
